\title{
6 Shū genre in manuscript cultures
}

He who controls the present controls the past, and he who controls the past controls the future ${ }^{1}$

The physical availability of written sources and flows of information are in a dialectical relationship, one fostering and stabilising the other. Steadying moulds of text production, stabilising networks of signification, sophisticated processes of entextualisation - they all occur predominantly in more mature manuscript cultures where written texts abound. ${ }^{2}$ The maturing of Shū genre too must be seen in this context.

This study suggests that the primary layer of Shū was in the first instance a repertoire of (speech) components in an archaic register, not fully fledged texts. These components were taken from, and informed the making of, the cultural capital of a meaning community with inevitably contrasting conceptual subgroups. Because of the cultural significance of these items, as well as the increasing access to this pool of information due to a democratisation of knowledge as ever more texts circulated in writing, penetrating and informing even relatively peripheral sub-groups of the wider Zhōu meaning community, ${ }^{3}$ ever-more social groupings made use of this pool when making arguments of sociopolitical and philosophical significance. Thus fostered by the flows of information, the manner in which this cultural capital was used by the different actors of the mid-Eastern Zhōu meaning community became more uniform, and the items of this pool became increasingly modular in the service of a variety of arguments.

This is exactly how genre channels the production and reception of a particular kind of text and, by extension, argument: it assimilates an utterance through its intertextual links with previous, related utterances. The sociohistorical reality thus created by a community's use of this repertoire rests upon the activation of

1 George Orwell 1949, in response to changes made in the Great Soviet Encyclopedia shortly after Stalin's death, removing an article on Lavrentiy Pavlovich Beria, the former chief of Stalin's secret police. (Rudy 2016: 1.)

2 Note that writing in manuscript cultures is just one technology enabling these processes; another is the complex production of oral text as seen on the Indian sub-continent.

3 On this development, see Meyer 2018a. The significance of this statement lies in the fact that even these more peripheral groups are aware of, and to some extent share, basic values and assumptions of the hegemonic Zhōu legacy.

2 Open Access. () 2021 Dirk Meyer/JAS, published by De Gruyter. (c) BY-NC-ND This work is licensed under the Creative Commons Attribution-NonCommercial-NoDerivatives 4.0 License.

https://doi.org/10.1515/9783110708530-007 
a shared code-a community's cultural capital-serving as conventionalised framework for the 'production, reception, and circulation of discourse'. ${ }^{4}$

It is clear therefore that the modular speech components cannot stand on their own for them to serve a group's needs. Rather they operate as the intertextual juncture by which groups, even peripheral ones, connect their narratives to a wider discourse practice and link their experience to the 'knowledge stored by a culture'. ${ }^{5}$ By relating their concerns to a discourse through intertextual links common of Shū genre, different groups acquired a tool that enabled them to fashion new texts through which they could formulate their own sociophilosophical thinking, and give it ancient pedigree.

By thus weaving old cultural capital into new argument space, a discourse emerged where the past was retrospectively systematised to justify claims of rulership in the present. Certain features thus became a requirement in these texts for the participating communities to connect to this debate. In this way the participating groups generated an expectation and satisfied it at the same time. With different communities and their sub-groups expecting to find certain references that allowed these groups to tie an argument (and its makers) to a particular debate on good rule, key text features stabilised as they were repeated across different texts. With their archaic (or archaising) language, the excessive use of direct speech put into the mouth of ancient rulers, and the repeated framing formulae, as well as certain themes increasingly required in them, Shū became a genre which channelled the production of new text and hence new arguments.

\subsection{Old Wine in New Bottles}

With the narrativisation and the literalisation of old cultural capital in maturing manuscript cultures the texts of the time became increasingly complex. Dramatic features of text composition were now being used more widely. It is possible that silent reading too was beginning to develop. ${ }^{6}$ While it was probably still not common during the Warring States, certainly some texts in the traditions of Shū increasingly made for a good read. ${ }^{7}$

One particular feature of the increased complexity of the text is the 'extended event', which we see occurring in Shū texts during the Warring States period. It

4 Bauman 2004: 2.

5 Lachmann 2010: 301

6 The question of silent reading in antiquity is discussed in Bernhard Führer and Wolfgang Behr 2005.

7 See Ch. 5. 
results from the narrativisation and the literalisation of cultural capital through modes of entextualisation. The extended event in Shū genre transforms the social use of a text from the re-enactment of an (imagined) historical encounter-most likely in a ritual setting - to a specific sociopolitical and philosophical argument.

In "Gù mìng" (Ch. 4), for instance, the frame and the king's charge form the text's core. Structurally the catalogues of ritual description are supplementary. Yet together they portray an ideal of royal succession. While structurally the catalogues thus form a 'secondary' element, no matter their previous contexts, entextualised in "Gù mìng” they serve to systematise retrospectively ideas about, and the praxis of, statecraft.

Through modes of entextualising old cultural capital into new problem space, the 'secondary' elements-for instance elucidating narrative, additional speech items, catalogues of various sorts-the target text no longer just portrays the core (or 'primary') event, such as the king's speech. Instead, Shū texts now produce chains of responses to the primary event that function as 'sub-events'. Entextualisation thus enables the makers of these texts to tell a more complex story.

\section{2 "Wén Hóu zhī mìng"}

I would like to cite the contrastive example of a speech-only event to elucidate my point. For convenience I use "Wén Hóu zhī mìng" of the new-script recension of the Shàngshu.$^{8}$ It is a relatively brief text formed of just five building blocks. Headed by the event-immanent formula that commonly frames kingly speech in Shū genre, wáng ruò yue 王若曰 (the king spoke thus), ${ }^{9}$ it produces a

8 "Wén Hóu zhī mìng" is listed as Ch. 27 of the Western Hàn modern-script recension of Fú Shēng 伏胜 (268-178 BC); it is recorded as Ch. 28 in the recensions of the "Three Masters" that follow the "Fú Shēng modern-script" recension. During the Eastern Hàn (AD 25-220) the text was organised as Ch. 33 in the old-script compilation of Mă Róng and Zhèng Xuán. In the pseudoKǒng recension of the Eastern Jìn, it was arranged as Ch. 56. The dominant traditions of the Three Masters (sān jiā shī 三家師 - also referred to as the ‘Three Modern-script-Masters') 三家今文 denote the recensions attributed to Master Ōuyáng 歐陽氏, Xiàhóu Senior 大夏侯氏, Xiàhóu Junior 小夏侯氏. (These recensions all added the spurious “Tài shì” 泰誓 to their text corpus.)

9 The literature on wáng ruò yuē is vast and I am probably missing many important contributions to that discussion here. Seminal to our understanding of that phrase is the discussion by Chén Mèngjiā 1939 (reprinted in Chén Mèngjiā 1985 (and 2005): 143-166). Chén’s analysis has inspired a debate in China (but also in the West) about the particular meaning and purpose of that phrase. See, as exemples of that debate, Péng Yùshāng 2014; Zhāng Huáitōng 2008; Xīn Yíhuá 2002. For a reevaluation of the phrase, see von Falkenhausen 2011. 
royal address to someone referred to as 'Yìhé' 義(誼)和. ${ }^{10}$ The speech, which formulates a contractual exchange between ruler and subject, is the sole event of this text. Yìhé's role is being a passive recipient with no voice; the king's action is that of speech:

1. 王若曰:

父義和, ${ }^{11}$ 丕顯文武, 克慎明德, 昭升于上, 敷聞在下。惟時上帝, 集厥命于文王。亦惟 先正 ${ }^{12}$, 克左右昭事厥辟, 越小大謀猷罔不率從。肆先祖懷在位。 ${ }^{13}$

The King spoke thus:

'Oh Uncle Yihe (Yìhé 誼和)! Greatly illustrious were [kings] Wen and Wu. They were able to carefully make bright their charismatic power that it rose brilliantly on high (in Heaven) and had their fame diffuse widely on [us] below. And so it was that the God on High united his favouring commands ${ }^{14}$ on kings Wen [and $\left.\mathrm{Wu}\right] .{ }^{15}$ Then indeed it was so that there were ministers who could aid and brightly serve their sovereign, and further, in carrying out [our ancestors'] plans, great and small, there were none who did not follow them (our ancestors), and so [our] ancestors could be tranquilly in their position [on the throne]'.

2. 鳴呼! 閔予小子嗣 ${ }^{16}$, 造天丕徳, 殄資澤于下民 ${ }^{17}$, 侵戎我國家純, 即我御事, 罔或耆壽 俊在厥服。

'Oh, to be pitied am I, the little child succeeding [their position]; I inflicted [upon me] Heaven's great retribution, and so I cut off the resources and the bounties [that were dispersed so plentiful] on to the lower common folk; we suffered foreign attacks and invasions that brought severe disaster over our polities; even among those who manage our affairs, in my service there is no one of age and distinguished experience'.

10 Yì 義 is generally taken as Yì 誼. See for instance Zhū Jùnshēng (1788-1858) in his Shàngshū gǔ zhù biàndú (2115).

11 The pseudo-Kǒng explains fù as used because Wén Hóu was of the same xìng 姓 as the speaker. Yì Hé was used accordingly to set them apart. (2114f.) In his Shūjing jizhuàn (255), Cài Shěn (1167-1230) explains fù as uncle, pointing to the use of fù for denoting the same father. Yì Hé 義和 might have been a courtesy name, $z i$ 字.

12 Zhèng Xuán explains xiān zhèng 先正 as xiān chén 先臣, pointing to the qīng dàifú 卿大夫 'high officials'.

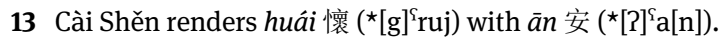

14 Legge 1960: 613.

15 My emendation follows the rhetoric structure of the text, which talks of the kings as a pair. This change is supported by the contextualisation of the text in a parallel passage in the Shriji: "Jìn 晉 shìjiā" (Hereditary houses, Jin), 68.

16 Another way of parsing the sentence would be to take it as 'Oh, to be pitied am I, the little child; in succeeding [their position], I inflicted [upon me] Heaven's great retribution'.

17 Sūn Xīngyăn interprests tiăn 殄 as jué 絕 'to bring to an end'; Zhào Qĩ takes zé 澤 as lù 祿 'official's salary. 


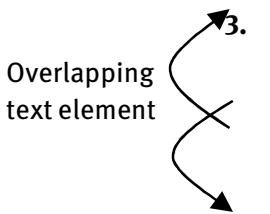

予則罔克, 曰: 惟祖惟父, 其伊恤朕躬。鳴呼! 有績, 予一人永綏在 位 ${ }^{18}$ 。

'Thus uncapable, I say: "my grand-uncles and my uncles, may you anxiously think of my person! Oh, if you have achievements, I, the one man, shall forever enjoy repose upon my position!”’

4.1 父義和:

汝克紹乃顯祖 ${ }^{19}$, 汝肇刑文武, 用會紹乃辟, 追孝于前文人 ${ }^{20}$ 。汝多修, 扞我于鎯 ${ }^{21}$, 若汝 予嘉。

'Uncle Yi He! You are able to assist your illustrious ancestors. You were the first to follow the example of [kings] Wen and Wu and thereby join in (hui) and continue (shào) [the efforts] of your king, to pursue the filialities toward the former accomplished men.22 You have on many occasions done best to defend me in [moments of] difficulty - someone like you, I find excellent (because of your merit)!'

4.2 王曰:

父義和, 其歸視爾師, 寧爾邦。用賚爾秬䍒一备23, 粀弓一, 䑣矢百, 盧弓一, 盧矢百, 馬四匹。父往哉! 柔遠能邇, 惠康小民, 無荒寧, 簡爾都, 用成爾顯德。

The king said:

'Uncle Yi He! You should return to oversee your armies and pacify your state. I thus award you with sacrificial liquor (made from millet and fragrant) of one vessel yǒu; $;^{24}$ one red bow

18 Liú Qǐyú suggests taking ji 績 ‘merit; accomplishments' in the sense of $z e ́$ 責 'hold responsible’ (in Gù Jiégāng and Liú Qǐyú 2005: 2119). That would render the sentence as 'if you hold responsibility, ...'.

19 The pseudo-Kŏng glosses shào 紹 as míng 明, which suggests that some text versions might have had zhāo 昭 'clear'. (See, however, the discussion in Karlgren 1970, gloss 2094.) There is now some concensus that in bronze texts shào 紹 should be read as zhào 詔 'to assist'. I read it in this sense too.

20 The phrase qián wénrén 前文人 'former men of accomplishment' appears repeatedly in the bronze texts from the mid- and late Western Zhōu periods. Except for "Wén Hóu zhī mìng" it is not found in the transmitted texts such as the Shìjing or the Shàngshū. The line "I have made announcement to the accomplished one' (告于文人) in the ode “Jiāng Hàn” 江漢 (Máo 262) marks the closest parallel to the phrase in "Wén Hóu zhī mìng”. More common is the reduction of the phrase to 'former men' (前人), which occurs repeatedly in the Shàngshū but in none of the other received texts, “Dà gào” 大誥; “Luò gào” 洛誥; “Jūn Shi” 君真; plus the old-script recension “Cài Zhòng zhī mìng” 蔡仲之命 and “Jūn yá” 君牙.

21 The term duō xiū 多修 has inspired all kinds of interpretations. I here follow Karlgren 1970 to take them in their most ordinary fashion. (See his gloss 2096.)

22 On the conceptual paring of Kings Wen and Wu, see Ch.4: 121n.5. For wén rén 文人 as 'accomplished person', see Schaberg 2001: 63ff.

23 The term yòng 用 expresses the consequence of the uncle's merit.

24 yǒ 占 is a type of wine vessel. It was during the Sòng that the textual yǒu was connected to the bronze object that now goes by that name, but none of them ever bear the self-description 'yǒu', and so we do not know what shape they had. 
plus one hundred red arrows; one black bow plus one hundred black arrows; and four horses. Go, my Uncle! 'Be gentle to the distant [states] and connect with those that are near'; 25 'be kind to the minor commonfolks and tranquillise them'; ${ }^{26}$ 'don't you idly seek repose'; ${ }^{27}$ inspect and zealously attend to your capital, so that you may accomplish your illustrious charismatic power!'

\subsubsection{The Sitz im Leben of "Wén Hóu zhī mìng”}

"Wén Hóu zhī mìng" records no contextual information. There are no narrative elements situating the (imagined?) encounter in time and space. It does not produce an extended event and, isolated as it is, this speech-only event is structurally 'a-historical'. ${ }^{28}$

Because of its historical unspecificity, and thus uncomfortable openness, commentators of all ages have looked for historical situations into which they might slot this text historically to make full sense of it. In taking "Wén Hóu zhì mìng” as an actual recording of a historical reality, as they thus do, it is often understood as citing King Ping's (Píng Wáng 平王, r. 770-720 BC) speech to the Hóu (marquis) Wen of Jin (Jìn Wén Hóu 晉文侯, 780-746 BC), then the most powerful of the local lords. This reading was introduced by the highly influential Eastern Hàn commentator Zhèng Xuán, whom the pseudo-Kǒng commentary follows. ${ }^{29}$ Such historicising placement of essentially a-historical Shū speech is typical. ${ }^{30}$ It is the commentarial (i.e., imperial) substitute for the literalisation of cultural capital.

25 The phrase róu yuăn néng ěr 柔遠能雨 ‘Be gentle to the distant [states] and connect with those which are near' is common in Shū genre and appears repeatedly in bronze texts from the late Western Zhōu: Yīnzhōu jīnwén jíchéng 02836 and 04326. It also appears in the ode "Mín láo” 民 勞 of the Shijīing (Máo 253). See also “Gù mìng”, 3B.

26 Variations of that phrase appear in "Kàng gào”, "Wú yì”, "Dà gào”; “Zǐ cái”; "Luò gào”.

27 Variations of that phrase appear in "Wú yì".

28 I stress that 'a-historical' does not mean that the text is necessarily ahistorical in the sense that it lacks historical knowledge. (Meyer 2017a: 107.)

29 This assumption has now become the dominant reading of "Wén Hóu zhī mìng". See the discussion in Gù Jiégāng and Liú Qǐyú 2005: 2128-2136.

30 One prominent example is “Dà gào” (Great Announcement) where the King’s speech, framed just by the event-immanent formula wáng ruò yuē, is ascribed by most commentators to King Cheng 成王, while some take it as proncounced by the famous Duke of Zhou, Zhōu Gōng 周公. The urge of commentators to historicise both the orators of speech and the factual occasion of that oration is also expressed in the prefaces to the various Shàngshū texts. (For a discussion of the prefaces, see Zhū Tíngxiàn 1987: 4-20.) 
Yí Jiù 宜臼 was the legitimate heir apparent of King You (Yōu Wáng 幽王), the last ruler of the Western Zhōu, forced into exile by his father, the king. ${ }^{31}$ After the fall of the western capital, he was installed as King Ping (Zhōu Píng Wáng 周 平王) at Chéngzhōu 成周. ${ }^{32}$ The dominant forces behind this were initiated by the states of Jìn 晉 and Zhèng 鄭 under the principle aegis of the Hóu Wen of Jin (Jìn Wén Hóu 晉文侯). The two states, Jìn and Zhèng, were also active in facilitating the evacuation of the Zhōu elite from their Wei River homeland when it was overrun by Quǎn Róng 犬戌 tribes. ${ }^{33}$

Chéngzhōu had long been a stronghold of the Zhōu, and it provided the eastern states with logistical support. ${ }^{34}$ Leadership and military support from Jìn and Zhèng, as well as from the state of Lǔ 魯 which had been founded at the beginnings of the Western Zhōu, proved essential for the survival of the court in the new capital. ${ }^{35}$ King Ping depended hugely on these forces, to the point where he exchanged his son as a hostage for the son of the Gōng, Zhuang of Zheng (Zhèng Zhuāng Gōng 鄭莊公 r. 743-701). This was an unprecedented breach of the relation between king and vassal. ${ }^{36}$ The relationship even worsened after the death of King Ping, as the Gōng Zhuang of Zheng sent raids into the fields of the royal domain. King Ping's successor finally led an alliance of Chén 陳, Wèi 衞 and Cài 蔡 to attack Zhèng, which resulted in a disastrous defeat for the royal forces. The Zhōu rulers never recovered from this. Ever since, the Zhōu king was merely a nominal leader.

When projected against this background, "Wén Hóu zhī mìng” shows up the weakness of the Zhōu as King Ping delivers his stylised speech to the most powerful local lord of the day, the Hóu Wen of Jin (Jìn Wén Hóu 晉文侯). The text itself,

31 The entire account account, fictionalised as it may be, is recorded in the Hàn Dynasty work Shǐji: 4, 147.

32 Chéngzhōu 成周 is at present Luòyáng 洛陽, Hénán.

33 See also Shaughnessy 1999: 350; Li Feng 2006 presents a historical analysis of the crises of the late Western Zhōu.

34 Cho-yun Hsu 1965: 546.

I here ignore the question whether the importance of Luòyì 洛邑 was really one that was retrospectively explained, such that the 'reasons' for the relocation to the east came to be expounded conceptually only after that move. The position it occupies in the received corpus is noticeably disproportionate to that of the old capital.

35 Hsu 1965: 551. The “Xìnián” 繫年 (Annalistic History), one of the manuscripts in the Qīnghuá collection, offers further insight into the relocation, suggesting that King Ping even spent a few years in Jìn before actually moving to Chéngzhōu. For a discussion of the "Xìnián" as an attempt to date "Wén Hóu zhī mìng”, see Lĩ Xuéqín 2013, who thus dates to 750 BC.

36 Ibid., 552. 
however, does not determine this reading. Whether it really responds to that encounter-real or imagined-rests entirely on the retrospect projection of the otherwise not recorded name 'Uncle Yihe' 義(誼)和 as the Hóu Wen of Jin. Its structure suggests, however, it was not just used in such narrowing historical placing.

I do not wish to deny that "Wén Hóu zhī mìng” grew out of a particular moment in time. But its social reality within a community was not so static. Constructed in such an open manner, the setting in the life of "Wén Hóu zhī mìng" evolves whenever a community recites-and thus activates-it by rearticulating "Wén Hóu zhī mìng” in a given context.

\subsubsection{Speech in "Wén Hóu zhī mìng"}

Structurally, the speech in "Wén Hóu zhī mìng” can be divided into five building blocks of four sequential units as follows: First is the king's primary address to Yì Hé (1). ${ }^{37}$ It is headed by the event-immanent formula wáng ruò yuē, which marks the 'internal' frame to the speech. ${ }^{38}$ The speaker expresses two notions. One is the exaltation of Kings Wen and $\mathrm{Wu}$ as founding fathers of the glorious Zhōu, whose dé 德 ('charismatic power') was such that it encompassed the whole world. The other is the speaker's praise of their servants whose loyalty enabled Kings Wen and $\mathrm{Wu}$ to establish lasting patterns of rule.

Introduced by the genre-typical theatrical exclamation, wūhu 鳴呼, the speaker positions himself as the rightful successor of Kings Wen and Wu, and therefore the legitimate ruler over the Zhōu polity, but contrasts his own achievements, ritually, humbly, with those of the two kings. Lamenting the foreign intrusions into the Zhōu polity, as well as the hardship of the people, he formulates a 'uniform opposition' to the initial lines of the first unit. A conceptually parallel antagonism to his praising of the loyal ministers of the founding fathers of the

37 The numbers in parentheses relate to the structural organisation of the text as given on pages 188-90.

38 I differentiate 'external' from 'internal frame'. External frame denotes the narrative material that contextualises speech in a certain situation by providing a 'historical' (albeit possibly imag-


mìng”, which I dicuss in this volume, are examples of speech contextualised in this way. Internal frame (or event-immanent frame) are speech related structures that mark the speech by placing it in a-non-specific-sociopolitical context. 
Zhōu is thus produced..$^{39}$ This is further stressed by his lamenting the lack of devoted men who could help him order the state.

This segment of his speech (2) is countered by another exclamation (3). The orator again shifts focus, now turning to himself. It is claimed that those in his service should consider him the centre of their concern, so he may remain tranquilly in a position of power. Structurally, this element takes the form of a doubledirected text segment: it connects the laments about the lack of ministers (in 2) to a command and implicit request to Yì Hé expressed below (in 4). ${ }^{40}$ It rounds off the previous segment (2) by providing a counterposition to it and leading the whole speech over to the command (in 4). This puts a request to Yì Hé and frames the command in unit four by means of marked speech ('Thus X, I say Y'). The notion of an ideal state of tranquillity is important. It directly connects the speaker's utopian outlook to the initial reference point of his speech, that is, the glorious rule of kings Wen and $\mathrm{Wu}$. In this way, the orator establishes a parallel case in point, situating him implicitly in correspondence to these kings.

Last is the command to Yì Hé (4). The speech puts it in two parts. First is the explication of Yì Hé's achievements (4.1). Here he is put as the prime example of a man who, through his service, enables his lord to shine. But this part of the command is not just an appraisal of Yì Hé's service. Above all, it entails a strong prescriptive statement because it takes all those items listed in the previous speech elements that position the speaker parallel to Kings Wen and $\mathrm{Wu}$, and extends them to the domain of those in his service. By glorifying Yì Hé's service, the speech parallels Yì Hé in such a manner that he corresponds conceptually to the worthy ministers in the service of Kings Wen and $\mathrm{Wu}$. In this way, it presents a fervent appeal to Yì Hé - he must act like the men of old in service to Kings Wen and $\mathrm{Wu}$. And just like them, he must work diligently for the wellbeing of his ruler. The final element of the speaker's command therefore closes by announcing a reward that will serve to remind Yì Hé of his duty (4.2). This portion of the speech is interspersed with stock phrases that appear repeatedly in bronze texts, as well as in Shī and Shū traditions. Such intertextual referencing that to the outsider might appear as hollow, clichéd attempts to embellish speech actually adds gravity to the speaker's words. Moreover it stresses the tradition within which Yì Hé's service is rooted, signalling continuity in the relationship of a subject serving his lord.

39 The literary device of 'uniform opposition' in early Chinese meaning construction is discussed in Meyer 2015: 303.

40 On the literary device of a double-directed text segments, see Meyer 2011: 58. It is related to the double-directed parallelism discussed in Gentz 2006. 


\subsubsection{The Gestus of "Wén Hóu zhī mìng”"}

"Wén Hóu zhī mìng” signs each of its five speech components $(1 ; 2 ; 3 ; 4.1 ; 4.2)$ through explicit markers. The first of these is wáng ruò yue, 'the king spoke thus'. The phrase frames the first of the five speech elements, as well as "Wén Hóu zhì ming" as a whole..$^{41}$ By way of this frame, the text takes on a passive construction and assumes the rhetorical fabric of a report. ${ }^{42}$ "Wén Hóu zhī mìng" is thus presented as a neutral testimony of a ritualised occasion. The text presents itself in the manner of Western Zhōu bronze texts.

The remaining four speech elements each take the abbreviated phrase 'the king said' (wâng yuē 王曰) or other types of speech-markers, such as the king's exclamation wūhū 'ah, alas'; or they use the name of the addressee of the king's speech, which takes the rhetorical form of an exclamation ('Uncle Yi He!'). The marker of speech in the third component is interesting, for yue in the sentence 予 則罔克, 曰 ... (thus uncapable, I say...) introduces a new subset which is synctactically subordinate to the preceding. This is peculiar because in Western Zhōu bronzes yue normally frames speech not as the header of a sub-clause. ${ }^{43}$ It is but one of the elements suggesting a later text intervention. "Wén Hóu zhī mìng” embodies the tension between the Gestus of a Western Zhōu bronze text and later text making.

Elements of Western Zhou inflexion mainly apply to the macro-outlook of the text. They include: the a-historical nature of text that is bare of any narrative

41 As is true of bronzes, the phrase wáng ruò yuē in general only introduces the first speech element of a text. Subsequent elements are introduced only with the abbreviated formula wáng $y u \bar{e}$ 'the king said'. (See also von Falkenhausen 2011: 265.)

42 That is true even when assuming that wáng ruò yue should be translated similarly to Western Zhōu bronze texts, as 'thus spoke the king [approvingly]', read out by a Secretary, and part of the appointment document. In any case the word $y u \bar{e}$ requires a translation in the past-tense. (von Falkenhausen 2011: 240-241.) Alterations of the formula 'wáng ruò yuê' appear, for instance, in “Băo diăn” (Precious Testimony) of the Yì Zhōushū where we find: 王拜曰: 格而言 ... (The king bowed and said: 'true [indeed] are your words! ...'.) The phrase occurs in the situation of a ritual where the king hands to his servant objects deserving their respect. The formula here 'wáng X yue ' and the adverb ruò is replaced by the description of how he is bowing as he holds his address. The deviation from the basic formula wáng ruò yuē indicates even more explicitly the reported character of the event.

43 Note, however, the relative synctactical similarity with phrases like 縣改奉揚伯夷父休, 曰 : ... (JC 04269) ‘[I], Xiàn Jǐ, present and extoll the beneficence of Bó Yífù, [and thus I] say: “...” ’. If we moreover understand 則罔克 as an adverbial modification of $\boxminus$, then it is somewhat similar to bronze texts saying X 拜手稽首曰.... " bowing prostrate and touching [my] head to the ground, I say “...”'. As such subordination is not marked there remains a certain degree of arbitrariness. 
structures; its rhetorical fabric suggesting an intimate audience well informed about the reported event (no matter its historical reality) and, related to this, its thus posited non-representative illocutionary force; ${ }^{44}$ the singular, that is, unextended nature of the event-the king's speech-which covers just one particular moment in time and portrays it as a real-time happening.

For philosophical argument-based texts such a lack of contextualising features would normally mean that the argument travels less well among communities because the lack of information means it is itself too elliptic. In Shū genre this is different. A speech-event such as this one appeals precisely because the lack of contextualising elements means it can be used in a variety of contexts and occasions, entextualised in different settings, textual or not..$^{45}$ The speech-event therefore becomes modular within the cultural bounds of text formation in Shū genre.

Features of post- $8^{\text {th }}$ c. BC intervention mainly pertain to grammatical and ideological shifts. The use of $y u \bar{e}$ as a marker of a subordinate clause has already been mentioned. The repeated focus on Kings Wen and $\mathrm{Wu}$ as paragons of the ideal ruler may be cited too, albeit with caution. ${ }^{46}$ Even though this pair-image took shape during the Western Zhōu, ${ }^{47}$ as a concept, it took more definite shape during the Eastern Zhōu period when comparable idealisations of the golden past were needed to enforce-in fact construct-the legitimacy of the exiled house of the Zhōu. The retrospective systematisation of the rulers' explicit concern for the wellbeing of the people as a goal in itself, typical of Eastern Zhōu sociopolitical thinking, should also be mentioned. ${ }^{48}$

"Wén Hóu zhī mìng" embodies the tension between pre- and post- $8^{\text {th }}-c$. BC attributes. It looks like an Eastern Zhōu artefact that was (re-)articulated by those communities to whom the sociomaterial setting of Western Zhōu (bronze) texts ${ }^{49}$

44 The differentiation between illocutionary and perlocutionary acts goes back to Austin 1962 . The perlocutionary act is the effect an illocutionary act has on the listener, intended or not.

45 This is of course different from the rhetorical approach of Western Zhōu bronze texts which seek to caputre the immediacy of s single ritual event.

46 See Ch.4: 122:9.

47 Examples from mid-Western Zhōu include the following bronze inscriptions: Hōng-gǔ 訇笽 (04321); Dong 或-guǐ (04342), Shī Kè-xǔ 師克㣱 (04467)

48 See, however, the discussion of the related concept 'Mandate of Heaven' by Mercedes Valmisa (2012) which hypothises its presence in some form during the Western Zhōu.

49 The 'materiality' of a text is of course not exhaustively captured in the naïve empirical or positivistic sense. I am here emphatically not talking about a hypothetical, physical encounter of the said communities with Western Zhōu bronzes, which has then led them to compose "Wén Hóu zhī mìng”. For my use of 'materiality', see the Introduction (Translocation of Writing), n.30.) 
and their Gestus of representation was still present, and they fashioned the text on this model. ${ }^{50}$

While "Wén Hóu zhī mìng" lacks obvious rhyme schemes, it contains a compelling sound texture and rhythm. Some of its lines are framed phonetically, so that the initial and last word of a line feature the same main vowel; some may even rhyme. ${ }^{51}$ The focal statement of the text-it is expressed right after the king is listing the merits of the implied addressee and as he is just about to announce the contractual gifts-'someone like you, I find excellent' (4.1: 若汝予嘉), is stressed phonetically through the consistent use of the open main vowel ' $a$ ' (若


time. This sentence is also surprisingly close phonetically to the framing phrase of the text, wáng ruò yué (王* $\mathrm{G}^{\mathrm{w}}$ an- 若*nak-曰* $\left.{ }^{\star}\right]^{\mathrm{w}}{ }^{\mathrm{w}}$ at), and so perhaps relating the two phrases conceptually by means of a phonetic web. ${ }^{52}$ Thus presented, the speech-event of "Wén Hóu zhī mìng" is highly compact.

"Wén Hóu zhī mìng" is a formalised oration, paired with a highly predictable language. This is typical of ritualised speech. The text is replete with first- and second-person pronouns; it refers to the speaker in the ritual self-style of 'I the small child' (予小子), and time and again it uses the ritually humble self-depiction of the speaker as against the paragons of high civilisation, Kings Wen and $\mathrm{Wu}$; the stylised, trifling and clichéd exclamation wūhū (oh; alas) with which the king introduces his words also fall into such hackneyed speech patterns. ${ }^{53}$ As predictable and clichéd as its language, so is the little information it actually provides. As is typical of speech in Shü genre, it is divorced from every day contexts and use. In its formalised, stereotypical, and artificial dictum, it is what the British anthropologist Maurice Bloch would call 'impoverished' ${ }^{34}$ The purpose of such language is therefore not primarily to pass on information; it is recurrent, ritualistic recitation.

50 The point of saying the text appears as an Eastern Zhōu effort at Western Zhōu style is not to attempt a dating of "Wén Hóu zhī mìng”, but to highlight the dynamic processes underlying such text making, which drew on practices rather than fixed texts in the first instance.

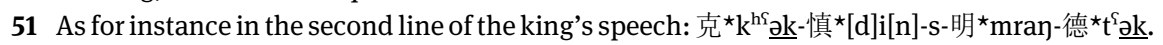
52 The core of the text is thus 'someone like you I find excellent!' of the king's declaration. On the structuring of texts through rhyme webs, assonances etc, see Behr 2004.

53 See also the discussion of ritual speech in Western Zhōu bronze texts by Kern 2009: 184-188. 54 Bloch 1974: 67. Founded on the ethnographical analysis of Merina ritual discourse, Bloch developed the hypothesis about the relationship of formalisation and force in ritual language. Analysing the political oratory and the circumcision rites in Merina discourse, he suggests that the instrument of persuasion in such discourse makes use of coercive devices of traditional authority. (Boyer 1990: 82) 


\subsubsection{A Modular Reading of "Wén Hóu zhī mìng"}

According to Bloch, in ritual settings impoverished forms of artificial, formalised language produce meaning proportionally to the degree in which propositional force is reduced..$^{55}$ The information it carries becomes secondary, the speech patterns become more predictable. The language is 'coercive'. With the reciter given no room but to accept or deny the 'imposed utterances', it becomes ideological. ${ }^{56}$

Whether one accepts Bloch's analysis of ritualised speech in every detail is of lesser importance here. Crucial is the description of impoverished language of a formalised speech event where the information is reduced to a minimum and becomes secondary. What matters to the communities in question is now primarily the social presence of the text and its use in a sanctified setting, not what it says in words. Meaning is primarily determined by repetition, not exegesis. Reciting "Wén Hóu zhī mìng” in a ritual setting-or reproducing it in writing-becomes a performance-activity that is making manifest, time and again, the 'contractual' exchange between ruler and subject - irrespective of historical actors.

"Wén Hóu zhī mìng” celebrates the loyalty between lord and subject in a highly generic manner. The act of recitation (or its written reproduction) repeats that contract. It becomes an integral part of the discourse of the participating meaning community who uses the text, and thus rewrites its applications in the present whenever they do so. In this way the social presence of the text helps to convey, sustain, and institutionalise an invented, imaginary, orthodoxy. Parallel to the ways the experience of the present is dependent on the perception of the past, the image of the past now legitimises present social order. ${ }^{57}$

According to the British social anthropologist best known for his work in memory studies, Paul Connerton, something is commemorative insofar as it is performative. The performative relies on habit, while habit depends on repetition and automatism. ${ }^{58}$ The Sitz im Leben of "Wén Hóu zhī mìng" is best described accordingly. The formalised-albeit possibly constructed-'re'-enactment of the ritual event it embodies makes manifest in the present the posed validity of the ancient contract between subject and lord. Whether some communities associate the speech-event with a certain ruler is therefore secondary. Most likely this differed from community to community. What matters is the ritualistic use of the

55 Cf. Bloch 1974: 67.

56 Boyer 1990: 83.

57 See Connerton 1989: 2.

58 See Connerton 1989: 4. 
text: it is continually dynamic, ultimately a-historical, and necessarily repetitive. In its ritualistic use it is modular; in its modular use it is necessarily ritualistic.

\subsubsection{Shaping Cultural Capital}

“Wén Hóu zhī mìng” is not culturally unique. In fact it has a close counterpart in a bronze text, the Máogōng-dǐng 毛公鼎, long considered spurious but now generally assumed to date to the late Western Zhōu period. ${ }^{59}$ Although nearly twice as long as "Wén Hóu zhī mìng”, the text cast in the Máogōng-dǐng essentially shares the same basic structure as "Wén Hóu zhī mìng”. It presents a king’s address to someone referred to as 'Sir Yin' (Fù Yǐn/Ān), in five similarly structured speech elements. Much like "Wén Hóu zhī mìng”, it follows the usual tripartite structure discoursing on past glories, present-day hardship, and future outlook; and it also closes with a contractual list awarded to Fù Yĩn for his service. Differences between the texts apply; ${ }^{60}$ but the commonalities are so striking that one was even considered as a model text for the other. ${ }^{61}$ I shall offer an alternative interpretation.

Around the ninth century BC there occurred an overall shift of ritual paraphernalia in Western Zhōu bronzes. This shift, generally termed 'ritual reform', ${ }^{62}$ reflects profound social change. The ritual reform introduced aesthetic changes

59 Máogōng-dǐng records a text in just under five-hundred graphs (497), arranged over thirtytwo lines. (Shāng-Zhōu qíngtóngqì míngwénxuăn, vol 3: 316). For a bronze from the Western Zhōu period it is exceptionally long. Máogōng-ding was long considered a nineteenth century forgery. Based on their close correspondences, Noel Barnard (1965; 1974) considered "Wén Hóu zhì mìng" as one of the potential inspirations for forging the Máogōng-dǐng (Barnard 1965: 399, 403; 1974: 6-7). Other voices doubting the bronze include Shirakawa Shizuka 1964 and Xú Zhōngshū 1984. However, $\mathrm{x}$-ray techniques have now made visible the spacers, indicating the authenticity of the bronze (Shaughnessy 1991: 59n39).

60 These include in particular grammatical differences such as the syntactical $y u \bar{e}$ and the exclamatory wūhū as a speech-unit marker of "Wén Hóu zhī mìng”. (That formula also appears in Máogōng-dǐng but not in the same way as a marker for speech-units.) In "Máogōng-dǐng, each speech-unit is marked by the repetitive ‘wáng yuē: Fù Yĩn/Ān' 王曰: 父庴 (the king said: 'Sir Yin!') While Máogōng-dǐng is thus structured more stringently in its explicit markers, "Wén Hóu zhī mìng" is more balanced in its correspondences of the different text-units, and it is closer in structure of composition to the argument-based texts of the Warring States.

61 See note 59; Barnard 1965: 399, 403 assumed a direct relationship of the texts. Shaughnessy 1991: 75 suggests that Máogōng-dǐng as a model inspired the production of "Wén Hóu zhī mìng”, a view criticised sharply in von Falkenhausen 1993: 163n46.

62 Sometimes referred to as a 'ritual revolution', 'reform' is probably the more accurate description of the changing patterns in the paraphernalia of ritual sacrifice at the time. 
in the objects, ${ }^{63}$ and it led to changes in the texts cast or inscribed in them. Bronze ornaments became increasingly abstract while the texts they carry became ever more generic. They become 'unvarying', ${ }^{64}$ such that we can speak of an overall standardisation of the bronzes and their texts. ${ }^{65}$ Albeit beautifully written, they are more 'stereotyped in content', showing reduplicative patterns of text production. ${ }^{66}$ These developments produced a centuries-long lasting legacy, with incessant patterns of cultural reproduction shared by wider groups.

While in Western Zhōu memory production, it is conceptually difficult to separate the text from the object that carries the text and the historical event both commemorate, this tripartite relation of object, text, and event is increasingly weakened by the Eastern Zhōu period. "Wén Hóu zhī mìng” is a good example, as it travelled independent of the material carrier that crucially defines its Western Zhōu counterpart, the Máogōng-ding (and other, similar texts) - a natural development in an environment where the making of a bronze text was no longer tied too intimately to a specific historical event. Cultural capital was becoming increasingly adaptable. But that is to be expected. The Swiss historian Kurt Raaflaub reminds us that the ancients' commitment to truth differs from modernday ideas of objectivity ${ }^{67}$ Present-day traditions of record-taking are ultimately shaped by nineteenth-century ideas about historiography, influenced profoundly by Ranke's (1795-1886) dictum that we show 'how it really was' (wie es eigentlich gewesen). ${ }^{68}$ But there is no point-for-point equivalence in antiquity. ${ }^{69}$

63 For a discussion of such changes, including the typological repertoire, epigraphy, as well as the constellation of bronzes as buried in tombs, see Bagley 1980; Rawson 1988; Rawson 1990; von Falkenhausen 1994; Luó Tài [von Falkenhausen] 1997; von Falkenhausen 1999 (with further references 150, n.13).

64 Rawson 1999: 438.

65 von Falkenhausen 1999.

66 Rawson 1999: 439.

67 Raaflaub 2014: 2.

68 What Ranke's statement 'wie es eigentlich gewesen' (showing what essentially happened) actually means precisely is an issue of ongoing debate. (The translation here follows Evans 2000: 17). Scholars such as Evans hold that Ranke was above all a romantic and idealist, with 'eigentlich' referring to the essence behind the facts which the historian should discern. (See also Iggers and Powell 1990).

69 A similar point is made in Goldin 2008: 80. See also Vogelsang 2005.

Ranke's dictum was stated in the preface of his Histories of the Latin and Germanic Nations from 1494-1514 (1887). It is discussed in Stern 1973: 57. See also the highly informed discussion in Rüsen 1990. 
The ancients' commitment to truth was instead concerned with preserving the memory of great deeds, serving primarily as exhortations to an ideal. ${ }^{70}$

Commemorating an ideal-rather than an actual-event, the ritual text is transposable to more than just one, historical, occasion. In its generic form it is, as discussed, modular in its application. In this way it shapes a prescriptive mould that allows variation. I believe this model is closer to the reality of the kind of text reduplication seen in "Wén Hóu zhī mìng” and Máogōng-dǐng. To suggest a mono-causal relationship between the two falls short because it randomly prioritises certain, occasional, text witnesses rather than considering long-term trends.

\subsection{The Extended Event and the Making of an Argument in Shū Genre}

Cultural capital divorced of its socio-material setting forms the source of the language of Shū genre. Paired with stabilising manuscript cultures where information flows better, it becomes ever more suited for the making of an argument of sociopolitical and philosophical import. This is through modes of entextualisation by different conceptual groupings who marry old and new to produce arguments that are novel yet persuasive as they claim high antiquity on their side. The extended event in the written traditions of Shū is symptomatic of this. It gives evidence to the sophisticated literary culture that is maturing at the time.

This does not mean that the texts of the second half of the first millennium $\mathrm{BC}$, in particular the Warring States, are necessarily growing in length. Unlike the transmitted-imperial-Shàngshū, the Qīnghuá manuscript texts are mostly rather short, even when structurally they produce an extended event. The length of a text and the type of event presented in it are therefore not corresponding features.

Exemplary of the extended event with pronounced dramatic features in brief

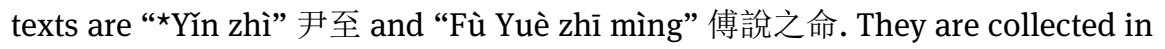
volumes 1 and 3 of Qinghuá Manuscripts.

70 Raaflaub 2014. See also Kern 2005b: 57ff. The famous case of the Shǐ Qiáng-pán confirms this. Produced just a few generations after a decisive battle, it celebrates success while really the king suffered humiliating defeat on that campain. 


\section{4 “*Yín zhi” 尹至}

“ネYĩn zh”” 尹至 is a formerly unknown iteration of the retrospective imaginings about Yĩ Yĩn and Chéng Tāng. It is recorded on just five bamboo slips, circa 45 centimetres long. It recounts Yī Yĩn 伊尹, travelling from Xià 夏 to Shāng 商, to report to Chéng Tāng 成湯 the hardship of the people of Xià as inflicted upon them by their ruler. As Heaven sends omens revealing the wishes of the commonfolks, the two swear allegiance to punish the Xià.

Some aspects of the fabula resonate with texts of the Shàngshü. The modern script recension “Tāng shì” 湯誓 comes to mind. While “帒 zhì” has no obvious counterpart in the received tradition, the editors of Qinghuá Manuscripts note that the phrasing partly resembles "Shèn dà" 慎大 of the Lü shì Chūnqiú. ${ }^{71}$

The manuscript bears no title. The current title was assigned to it by modern editors based on its first line: '[Yī] Yĩn had travelled from Xià to Bó (the Shāng capital) and by midnight [he] arrived at the place where Tāng was'隹(惟)尹自題 (夏)㗔(徂)白(毫)急(冓)至才(在)湯. ${ }^{72}$ The slips were connected by three cords, at the very top above the first graph; at the very bottom below the last graph; at the centre. Especially on slips one and four it seems as though there was additional space left between the graphs (15 and 16) where the central cord used to be. This opens up the question whether the writing was applied after the manuscript was bound.

Fully written slips carry between 29 to 32 characters. ${ }^{73}$ The physical properties of the slips and the calligraphy on them are identical to those of "^^ĩn gào", which is also part of the Qinghuá manuscripts. It seems that the writing was carried out by the same hand and the slips were probably produced at the same workshop. They carry double line markers for repetition (twice on slip 1; once on the final slip 5), single-line text markers indicating position-changes in the text (once on slip 2; once on slip 3; three times on slip 4), as well as a final mark signalling the end of the text (on the bottom of slip 5). No further writing is applied after that mark. I return to these marks further below.

The writing on the slips is well preserved. Only the top graph on slip $2(2 / 1)$ is no longer completley visible. The slips are numbered on their back consecutively

71 As stressed repeatedly, we should not deduce a direct connection between the two random text representatives (199). Among many possibilities, the texts may be informed by a common source or discourse, textual or otherwise.

72 Slip 1/1-10.

73 Slip 1 carries thirty-one graphs; slip 2 carries thirty-two graphs; slip 3 carries thirty-one graphs; slip 4 carries just twenty-nine graphs; slip 5 carries thirty graphs plus a final mark. 
from one to five, written clearly in ink at the lower upper third of the slips. Interestingly, the height where the numbers are written on slips 1 to 3 is identical, and so is that of slips 4 and 5. However, in the latter group it is placed a good deal lower. This is rather exceptional. ${ }^{74}$ While it may be assumed from this that the identification of the slips as one manuscript is mistaken, the text itself does not support that conclusion. The story progresses well from slips $1-3$ and 4-5, with no obvious break between the former group of slips and the latter. While the manuscript properties suggest that writing on the slips came after binding them together, the numbering was possibly done before binding them into one entity. This might suggest that the writer had had a good estimate of the physical length of the text he was about to produce. A reasonable explanation is that he might have been working from a written Vorlage when copying the text under review. This and the fact that more than just one set of slips went through the hands of this unknown writer suggests that he was working in a professional workshop.

The place where the numbering appears differs in colouring. It looks as though it had been shaven off before the writing was applied. Possibly because the slips were thinned accordingly, fine cracks apply to some of these places. ${ }^{75}$ At times these cracks go right through a graph, suggesting that the writing on the slips is contemporaneous to the preparation of the slip in question or, at least, predates the cracks in them. ${ }^{76}$ There is no slanting line produced at the back of the slips.

According to the progression of events, I divide the text into roughly three main constituents, $\mathrm{ABC}$, preceded by an initial frame that situates the text in an imagined historical context. I further subdivide $\mathrm{A}$ and $\mathrm{C}$ into two sections each.

Frame a $\left.\right|^{1}$ 惟尹自夏徂毫, 冓至在湯。

b 湯曰: 「格, 汝其有吉, 志。」

74 While this is an exception of the rule, "^Yĩn zhi” is not the only text that presents such features. Another case in point is "Yīn Gāozōng wèn yú sān shòu” (Qīnghuá Manuscripts v. 5). It is written on 28 eight slips, all of which numbered consecutively at the back of the slips from 1-28. (Note, however, that Slip 3 is missing, but it can be assumed that that slip too carried a number.) The slip numbers 1-7 are recorded at the top of the lower third of the slips; 8-15 are recorded at the bottom of the upper third of the slips; Slip 16 carries that number slightly lower than Slip 15; slip numbers 17-28 are again recorded at the top of the lower third of the slips.

75 Namely on slip three where a fine crack is going right through graph $3 / 9$ at the front of the slip and the number three at the back; on slip four a fine crack goes through the number at the back.

76 The image on p. 199 shows the crack on slip 3 that goes through the graph on the front side of the slip [3/9] and the number on its back. 
$\left.\right|^{1}$ [Yī] Yĩn had travelled from Xià to Bó (the Shāng capital) and by midnight [he] arrived at the place where Tāng was. ${ }^{77}$

Tāng said [on this occasion]: 'Come forward! May you have [something] good to report!?78

A1 尹曰: 「后, 我來廷。今恂恂余閔。

其有夏，眾 $\left.\right|^{2} \square+$ 吉好; 其有后，厥志其爽。

寵二玉，弗虞其有眾。民允曰: 『余及汝皆亡。』

惟災虐德暴重, 亡。」

Yī [Yĩn] said: 'My Lord! I have come to [your] court. I shall now courteously accord with your wishes.

As for the Xià the $\left.\right|^{2}\{\}$ (nature/character?) of the multitudes is auspicious and well disposed; [but] as for their lord, his intentions are erroneous.

[He] indulges in his two jades (viz., women) ${ }^{79}$ but shows no consideration for the multitudes in the domain. [Thus] the commonfolks indeed say: "I and you, we shall all be ruined!"

Now that his violent character of disaster and cruelty becomes ever more severe ${ }^{3}$ [they are bound to] diminish'.

A2「典夏有祥，在西在東，見章于天。

其有民率曰: 『惟我速祸。』

咸曰: 『害今東祥不章? 今 $\left.\right|^{4}$ 其如台? 』」

'Omens to govern the Xià are at the east, as well as at the west - visibly do they appear in the sky;

The commonfolks [of the Xià] go along [these signs] and say: "it is us indeed, who shall soon encounter misfortune!”

[They] all say: "Why, now, are the omens to the east not visibly clear? ${ }^{80}$ Now, what does that mean to us?"”

B 湯曰：「汝告我夏䚈率若是？」

尹曰: 「若是。」

[Chéng] Tāng said: 'Do you thus tell me that, in examining the Xià, it is all like this?'

[Yī] Yĩn responded: 'It is indeed so'.

C1 湯盟誓及尹，兹乃柔，大縈。

77 The graph 1/7 䍃 appears similarly on slip 85 of the Ān Dà manuscripts in the ode 溸(牆)又 (有)㾮(䗊) 䖿(䖿) 'On the outer wall there is three-horned vine (tribulus)' (43 [Máo 46], Song 2 Yǒng 角) except that the phonophore xì 夕 appears on the left, not at the top of the graph (瞅). For a discussion of the graph see Ān Dà Manuscripts 1:4.

78 For a rendering of $j i$ 吉 as 'good', see Schwartz 2019: 78n. 8. Schwartz further cites “*Yĩn zhì” as a 'later example' (i.e., Warring States) of ji meaning 'good'. (Schwartz 2019: 80n.16)

79 The story of how he carved the names of Wăn 琬 and Yăn 琰 into jade appears in the Tàiping Yùlán that references the "Jì nián" in chapter 135, the "Shèn dà" chapter of the Lǘ shì Chūnqiū, as well as the "^Róng chéng shì" from the Shànghăi collection of Chǔ manuscripts. The origin of that story is not known.

80 The Shāng were at the East of the Xià. 
[Chéng] Tāng [thereupon] contracted an oath with [Yī] Yĩn. Although this was done concilliatorily, it was greatly binding.

C2 湯往 $\mid 5$ 征, 弗宥。摰度摰德, 不僭。

自西殘西邑, 㽎其有夏。

夏播民入于水, 曰: 「戰。」帝曰:「一勿遺。」 $\mathbf{L}$

Tāng went and $\left.\right|^{5}$ marched [against the Xià] without forgiveness; Zhì was restrained and showed charismatic power, never overstepping his authority.

From the West [of Bó], they destroyed the Western capital (viz. the capital of the Xià), [thus] they gained victory over the Xià.

The Xià relocated the commonfolks into the water and shouted: 'to battle!

The $\mathrm{Di}^{81}$ proclaimed: 'not one is to be spared!' $\mathbf{L}$

The frame stages an encounter of Yī Yĩn and Chéng Tāng and structures the conquest of the Xià by the Shāng in narrative terms. The stage-like opening constructs a dramatic setting. I take Tāng's initial address to Yī Yĩn as part of the text's frame because it structures Yĩ Yĩn's subsequent address ideologically, while keeping A structurally intact.

What follows is organised in three parts (A, B and C). The first, A, specifies the reasons for Yĩ Yĩn's alleged visit to Bó, the capital of the Shāng. Except the event-immanent introducing formula, '[Yī] Yĩn said' (尹曰), it consists only of Yī Yĩn's address to the king, Chéng Tāng, reporting on the condition of Xià.

Unit A can be subdivided. A1 reports the cruelty of the Xià against their own people; A2 brings in the cosmic sphere where omens forecast the end of the Xià. They signal that the Shāng uprising is legitimate, commanding to end Xià's cruelty by introducing the rule of the Shāng for the people's benefit. Their wish for Shāng insurrection is clear from the last line of A2, as they look for omens in the east, the place of the Shāng.

At the end of A2 there is a black mark on the slips. It coincides with a shift in the narrative mode of the text (iiㅁ). Yì Yĩn's lecture, in which he repeats the people's wishes, has ended ${ }^{82}$ Tāng's response comes in, seeking to confirm Yì Yĩn's assessment of the situation (in B). The shift is signalled by another black mark. Next is Yĩ Yĩn's brief but powerful validation of what has been said. It is yet again followed by a black mark, the last one on the manuscript, signalling the finality of the text in B. The way these marks are used suggests they serve as 'perspective markers'.

81 Title of the Shāng ruler.

82 It is this black mark that makes me read 今 $1^{4}$ 其如台? 'now what does that mean to us' as part of the people's exclamation. 
Unit B presents a shift. It functions as a structural bridge that leads over Yī Yinn's observations from unit $\mathrm{A}$ to $\mathrm{C}$, where they are translated into physical action against the Xià. As is true of $\mathrm{A}$, unit $\mathrm{C}$ too contains two structural components. One is the pre-battle oath between Yī Yĩn and Tāng (C1); the other presents the war against the Xià (C2). Like the act of divination in “*Zhōu Wǔwáng yǒu jî”, the oath in $\mathrm{C} 1$ is not itself described in the text. This is a typical feature of Warring States texts.

The portrayal of Shāng's takeover from Xià in C2 is in many ways worthy of attention. First is the length of that text unit. While the entire "^Y̌n zhì" consists of some hundred and fifty-six graphs, ${ }^{83}$ the actual takeover is given a mere thirtythree graphs - just about a fifth of the entire length of the text. The actual rebellion and its battles, it is clear, are of no central importance to the text. This is further evident from the fact that there is no description of the battle as such. The text merely states that they marched 'without forgiveness', with 'not one ... spared'.

Rather than focusing on the actual takeover, "^Yĩn zhì" is concerned with the legitimacy of that move. It portrays Chéng Tāng's concern that the takeover be in line with the will of the people of Xià and therefore supported by Heaven. Portraying that concern takes about two thirds of the text. ${ }^{84}$ The focalisation on Chéng Tāng's anxiety that he duly serve the people, move against the Xià, and thus satisfy the Heavenly order, is further supported by the text's narrative mode: dramatic in nature, it assumes a stage-like frame; it contains an intimate exchange between Yī Y̌ñ and Tāng; and it is characterised by the heavy use of personal pronouns of first and second order. ${ }^{85}$

“`Y̌n zhi” is not reporting the armed insurrection against the Xià. Rather, it is about the appropriateness of that move, as well as a leader's obligation to carry it out when necessary. The dramatic mode conveys urgency, with the dialogic speech patterns making it suitably acted out. Chéng Tāng, it becomes clear, only serves as a projection image, a first legitimising factor, highlighting a profound truth behind that 'historic' incident. “`Yĩn zhi” thus portrays reduplicative patterns of personal duty to serve the will of the people, and by implication, Heaven. Once established as an argument, the projected idea becomes-with different degrees of self-consciousness by the text producing communities-transposable to a wide range of sociopolitical and ideological situations.

83 That is, 155 graphs plus one that is missing and has to be added. This may be considered the typical length of a textual unit during the Warring States.

84 That is, developed in units A and B, 94 graphs plus one that is missing and has to be added.

85 The personal pronouns make a good fifteen percent of the entire text. 
This is also reflected in the Gestus of the text. Reporting the exchange between Yī Yĩn and Chéng Tāng, units $A$ and $B$ assume the constructed perspective of a witness who is present at the event. No broader perspective is assumed. That differs in the initial line of the frame, as well as in unit C. Here a post-event summary is given, providing a retrospective reflection that puts the event in a narrative context. In this manner, a distance from the reported event is staged. That distance is adopted again in unit C. C1 provides two things. One is the mention of the oath. The other is the placing of the event on a scale of importance. While the event itself is described as 'conciliatory', it is nonetheless 'greatly binding'. The narrative thus draws political conclusions. This is furthered in C2. As Tāng marched against the Xià, 'no forgiveness' was shown. Yī Yĩn-in C2 he is notably referred to as Zhì, his personal name-showed 'restraint' and 'charismatic power', and he never 'overstepped his authority' during that campaign. Chéng Tāng and Yī Yĩn are thus portrayed as the perfect match where minister and ruler fully complement each other. This is not the mode of a report. The highly rhetorical “^Yĩn zhi” serves different ends. It presents a well-crafted argument about rule sanctioned by Heaven - obviously a Zhōu invention that was systematised in Eastern Zhōu thought. Here it is used anachronistically for the Shāng, providing a 'historical' pretext.

The closure of the text, the Dì proclaimed: 'not one is to be spared!' (帝曰一 勿遺) is interesting, no matter who, we think, is actually the speaker of this line. One possibility is that it gives voice to the last ruler of the Xià. This may come as a surprise, for it seems to privilege the ruler of the Xià with the final words of this text - just before the battle. For a text that is so unequivocally composed from the perspective of Chéng Tāng serving the will of Heaven, this might seem unlikely. However, there is another spin to it. As Chéng Tāng is moving against the Xià, the Xià relocate their folks into the water, abusing them as a human shield. Contextually, the final exclamation by the Dì that, in his own words, "not one is to be spared' in a nearly physical way reinforces-literally cries out-the cruelty of the last ruler of the Xià. By putting this at the close, the authors of this iteration of fabula present him as the obvious counter-image to Chéng Tāng, whose prime concern is the common folk. As an alternative, Chéng Tāng is speaking, giving his actions legitimacy by calling him Dì even before he completed his campaign against the Xià. ${ }^{86}$

No matter who of the two is speaking, Chéng Tāng or the last ruler of the Xià, it is remarkable that “^Y̌̃n zhì” gives active voice to the Dì as Dì.

86 I do not want to exclude the possibility that the text is purposefully left open, a cliffhanger ending incentivising its audiences to consult further iterations of the Yĩ Yĩn fabula. 
In the received Shàngshū, only three texts do so by means of the formula "the Dì said' (Dì yue 帝曰): “Yáo diǎn”; “Shùn diăn”; “Yì jì” 益稷 - three texts of late production; the Yì Zhōushū uses the expression just once. ${ }^{87}$

It is worth noting that the phrase 'the Dì said' is absent from the entire body of bronze texts, even though Dì-also as Shàng Dì 上帝 (the Dì on High) and Huáng Dì 皇帝 (the Almighty Dì)-occurs numerous times in bronze texts, from the late Shāng to the Warring States. While in its early use Dì was probably the name or title by which Shāng and Zhōu kings addressed their High God, ${ }^{88}$ as far as the records beyond the Shàngshū suggest, as a royal title it probably not in use for living rulers before circa $288 \mathrm{BC}$, when the first rulers 'declared themselves to be western and eastern $d \grave{\imath}$ ' ${ }^{89}$ Just as in the late texts "Yáo diăn" and "Yì jì", the fact that Dì is here used to give active voice to a ruler (帝曰) further supports the hypothesis of late text production - perhaps not much before its manifestation on the very bamboo manuscript we are looking at. ${ }^{90}$

\section{5 “Fù Yuè zhī mìng” 傅說之命}

Another representative of the extended event as developed in a brief text is "Fù Yuè zhī mìng” 傅說之命 (The Charge to Yuè from the Rocks of Fù). ${ }^{91}$ Just as “^Yĩn zhì”, "Fù Yuè zhī mìng” shows many characteristics of a late Warring States-text and it provides further clues about text formation and the social use of Shū genre at the time. It tells the tale of how the King of Yīn 殷, ${ }^{92}$ Wǔding 武丁 (c. ?-1189

87 The old-script “Dà Yǔ mó” 大禹謨 also gives direct voice to a Dì.

In Gǔ shǐ biàn vol. 1, $200 \mathrm{ff}$, Gù Jiégāng suggests that the production of these texts falls between the late Warring States and the Qín and Hàn dynasties. In the Yì Zhōushū, the phrase appears in the chapter Harangues of Shāng 商誓.

88 See Keightley 1999: 252. Keightley further suggests that it could also refer to the royal ancestors of the main line of descent. The role of Dì, however, was non-ancestral in Shāng thinking (253). It was a supernatural element that could cause disaster. The Tiān 天 of the Zhōu was therefore capable of 'harming and destroying the dynasty'. (Ibid.)

89 Lewis 1999b: 637.

90 Dì was of course also used as a posthumous name of the last Shāng kings: Dì Yr̃ 帝乙 ( ${ }^{1105-}$ 1087) and Dì Xǐ 帝辛 (*1086-1045). (We find the former in Shāng bronze texts as Wén Wǔ Dì Yĩ 文武帝乙). Knowledge about these names was preserved in the Warring States-the Guóyú for instance mentions Dì Yĩ 帝辛 once in “Zhōu Yǔ shàng”: 商王帝辛, 大惡于民 ‘the Shāng king Dì Yĩ was greatly cruel to the commonfolks'-but the text producers probably no longer knew they refer to posthumous names.

91 Qinghuá Manuscripts vol. 3: 2-7; 121-131.

92 Yīn 殷 is another name for the Shāng that feature in the text “^Yĩn zhì”. 
$\mathrm{BC})$, received from Heaven the image of Yuè 說 that the latter become his minister. At the time Yuè was in the service of Yì Zhòng 佚仲. When Wǔdīng finally obtains Yuè, he commands Yuè to attack the polity of Yì Zhòng; thence, upon the successful completion of the campaign, making Yuè his minister, he charges Yuè with the affairs of his kingdom.

“Fù Yuè zhī mìng” has a remote counterpart in "Yuè mìng” 說命 (The Charge of Yuè), transmitted in three parts in the "Shāng" 商 section of the old-script recension of the Shàngshū. It records the king's address to Yuè delivered on his appointment as prime minister. However, as also acknowledged by the editors of the Qinghuá Manuscripts, we should consider the Qīnghuá "Fù Yuè zhī mìng” a text in its own right..$^{93}$

The transmitted "Yuè mìng" has no other rendition except the old-script recension of the Shàngshū. The Shǐji remains notably silent about its composition. This silence is peculiar and often taken as an indicator of the spurious nature of the text. Nonetheless, according to James Legge (1815-1897), the "Preface" ("Xù" 序), as well as the many references to it in the transmitted literature "leave no doubt' that there was originally a "Yuè mìng". ${ }^{94}$ The problems inherent in such claims are obvious. ${ }^{95}$ However, if we follow Michael Nylan in assuming that many of the texts in the old-script recension of the Shàngshū contain 'deutero-canonical' knowledge, ${ }^{96}$ there is no need to propose imagined stemmata of an immediate relationship between the old-script "Yuè mìng" and the Qīnghuá "Fù Yuè zhì ming". It is more plausible that the two texts relate to the same material, but worked it into different stories.

\subsubsection{The Text as Realised on Bamboo}

Just like the old-script "Yuè mìng”, the Qīnghuá "Fù Yuè zhī mìng” comes in three units. They each carry the designation "Fù Yuè zhī mìng”, written at the lower third on the back of the final slip. They are all written on slips of 45 centimetres

93 Qinghuá Manuscripts 3: 121.

94 Legge 1960: 249.

95 Legge's notion of 'references' to "Yuè mìng" in the received literature is problematic. While there are remote correspondences of phrases and notions seen in "Yuè mìng" and transmitted literature, there is no ground for assuming a linear reference of those items to "Yuè mìng" rather than the general recourse to known and widely shared concepts. That is especially true for socalled 'pre-imperial' texts and their relation to "Yuè mìng".

96 Nylan 2001: 132. 
in length. The slips are cut in a straight line at both ends, with three strings connecting them. With reference to the old-script text, the editors of Qinghuá label


(Yuè mìng middle part) and “^Yuè mìng” xià 下 (Yuè mìng lower part). No such order is marked in the manuscripts. I here follow the editors' designation of the manuscripts as *shàng, *zhōng, and *xià purely for ease of reference.

The slips of each of the three manuscripts are numbered on the back. But there is no slanting line. The text of *shàng is written on seven slips, and so is *zhōng; *xià was originally written on ten slips, but only nine of these remain. The initial slip of the *xià bundle is now lost. Each of the three entities is closed by the tadpole symbol (4). No writing appears after them. In the case of *shàng, slightly more than half of the final slip is left blank; the symbol appears at the bottom of *zhōng, and at the lower third of the final slip of *xià. (See their reproduction at the left.)

All three manuscripts contain mark-up. The calligraphy is uniform across the three units, but this is not true of the markings. Some are likely to have facilitated the reading of the text out aloud, possibly indicating breath marks for instance on slip 4/5 of * shàng. These are distributed fairly evenly across the manuscripts, ${ }^{97}$ but only ${ }^{\star}$ shàng contains regular markings for repetition one on slip 3; three on slip 4; two on slip 5, while ${ }^{\star}$ xià has just one on slip 6 and *zhōng has none.

Except for the missing slip in *xià, the three manuscripts are otherwise complete. No slip is broken to the extent that graphs are missing. There are also no cracks in the slips. While this is not unusual for a manuscript, ${ }^{98}$ I reiterate what I said about the importance of having documented excavations that allow us to work with the materials in full confidence of their provenance. This is particularly relevant for a text such as this one, where there is such a neat overlap of the "Xù" to the Shàngshū mentioning the existence of "Yuè mìng" in three parts, as well as the old-script recension with regard to the division into three. It is clear that had

97 In "Fù Yuè zhī mìng” *shàng eight such markers appear on seven slips: one on slip 2; one on 3; three on 4; three on 5. In * zhōng ten marks appear on seven slips: one on slip 1; two on 2; one on 3; one on 4; three on 5; one on 6; one on 7 . Thirteen such markers appear on *xià: one on slip 3; one on 4; two on 5; two on 6; one on 7; three on 8; two on 9; one on 10.

98 Note that the lengthy slips found in tomb 1, Guōdiàn, are in part also in remarkably good condition. The longest slips of the Guōdiàn corpus-excavated by archaeologists-are around

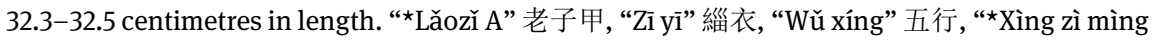

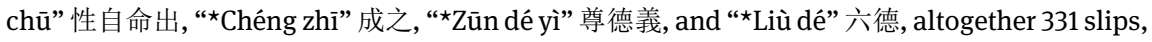
all fall into this category. Of those 331 slips, just 30, that is, less than ten percent, are in poor condition with slips broken. 
it been obtained through an overseen excavation it would vastly outstrip the present manuscripts in scholarly value.

\subsubsection{Text Division}

That "Fù Yuè zhī mìng" existed in-at least-three separate entities raises important questions about manuscript production and text circulation during the Warring States. It may be explained in principally two ways: first is the 'unityhypothesis' of text division. It follows the Qinghuá editors in considering the three items as integral parts of one text. Second is the 'fabula-hypothesis'. It suggests the items are each independent cases of textualised fabula of Wǔding making Yuè his minister.

\subsubsection{The unity-hypothesis}

The unity-hypothesis considers two alternative scenarios. The first is 'occasional'; the second 'structural'. The 'occasional' scenario prioritises the writing support available for producing the manuscripts. It implies that the given materialisation of "Fù Yuè zhī mìng" is accidental and says nothing about it as a text. This scenario makes two further assumptions. The first thinks that in this particular case the writer either did not have enough slips to produce "Fù Yuè zhì mìng" in full, so they simply split the text into three as they saw fit to match the available writing materials. The three units were then each designated "Fù Yuè zhī mìng" to indicate that together they form one single entity. The second thinks the text was produced in stages, possibly due to some form of labour division.

It is open to question how likely the 'occasional' scenario-of either sortreally is, as each of the three is marked as a closed entity: the tadpole symbol always appears on the final slip, leaving blank some part of it and marking a unit's end. The consistent physical features of the bamboo slips and the uniform hand which produced the writing on them also speak against this scenario. Therefore, rather than suggesting that a material deficiency lead to the partition of the text, it seems more plausible to think it the other way round, that is, arguing from the text, not the writing support: text-division was realised in the material. This is the 'structural' scenario of text division, to which I come next.

The 'structural' scenario suggests that at least some conceptual communities recognised "Fù Yuè zhī mìng" as consisting of three, and possibly more than three, parts. The fact that text partition was realised physically further suggests 
detectible, stable meaning clusters. It moreover suggests that more than just one copy of "Fù Yuè zhī mìng" circulated - for were there just one copy, what use would there be to impose text division and name its parts correspondingly? Furthermore, related to the previous point, given that the-much later-old-script "Yuè mìng" is also divided accordingly implies, conservatively, that during the Warring States, there was the prevalent condition for producing "Fù Yuè zhì mìng” in different parts, possibly three, perhaps more.

"Fù Yuè zhī mìng" in three parts thus confirms the overall picture of a stabilising textual condition during the Warring States where we see the division of a given text solidifying into various recensions. This unlikely went as far as in “Zīyi”,, which was clearly considered a stable entity in twenty-three units and marked accordingly (Ch. 2). It rather resembles texts such as Guōdiàn “^Xìng zì mìng chū" and Shànghăi "^Xìng qíng lùn” in that they were produced in an environment that inspired text division in different parts, while not securing them in such strict ways as in "Zìyī". 99

Obviously there is a-natural-asynchrony in the formation of recognised, stable texts. For texts to stabilise into known entities depends on many factors, including their language; structure; and the contents they deal with. Moreover, and crucially based on these factors, it depends on the accelerated rate at which a text was circulating, and thus the rate at which different groups would reproduce it for their own ends.

Take again "Zìyī". The discussion in Ch. 2 shows that it has attained a much greater stability than the foundational texts interwoven with it, especially Shū. While text recognition of "Zīyī" relies on the explicit integration of cultural resources, text stability was nonetheless achieved primarily through the highly concise structure of the compact building blocks that constitute it. They make it circulate well, to the point that "Zīyì" becomes the stable entity that it was during the Warring States; hence the near-identical copies of it in Guōdiàn and Shànghăi. Texts that are more complex in constructing their argument generally travel less well without change. Since argument-based texts are normally more specific in what they say in comparison to "Zīyi”, the rate at which they were reproduced by different communities was necessarily lower than that of "Zīyī". As well as their tendency towards alteration, (complex) argument-based texts therefore fall more easily into oblivion. ${ }^{100}$ Thus, while some texts attain stability, to the point that they become structurally closed entities (e.g., Warring States “Zīyī”), others simply inspire some sort of compositional repetition in the reproduction of the

99 See the discussion on 52-53.

100 Counterexamples exist and I discuss one, *Mìng xùn”, further below. 
text, without, however, being ever recognised as an entity-not least a closed one-by the conceptual communities in question (e.g., "Fù Yuè zhī mìng”, “^Xìng zì mìng chū”, “^Xìng qíng lùn”). ${ }^{101}$

\subsubsection{The fabula-hypothesis of text division}

Alternative to this is the 'fabula-hypothesis'. It assumes that the three manuscript texts "Fù Yuè zhī mìng” are simply independent renditions of a widely recognised fabula, rendered in different stories. Because of their common ground, the texts were collected under a common reference ("Fù Yuè zhī mìng") by a third party, possibly the writer in a workshop, or the collector. In this scenario the text is not the primary entity of recognition, but the fabula. It informs the communities in a variety of ways, with different versions circulating at the same time. Some, but certainly not all, of its manifestations were written down. This scenario suggests that the three are each an example of occasionally textualised matter, produced by a given social grouping at a given time. ${ }^{102}$ That they were nonetheless each designated accordingly confirms my previous points about the stabilising text condition during the Warring States.

101 It remains that the proposed structural organisation of "Fù Yuè zhī mìng" in three parts and the related conclusions regarding text formation during the Warring States are not indicative of an imagined relationship of an immediate order between "Fù Yuè zhì mìng" and the old-script "Yuè mìng", which by the way differ substantially. The first appearance of the "Yuè mìng" in the old-script recension was as late as the Eastern Jìn (317-420) when Méi Zé 梅賾 (or 梅陶) submitted a spurious version of the text to the throne.

Méi Zé held the position of Interior Scribe (nèi shǐ 內史) at Yùzhāng 豫章. When Emperor Yuán of Jìn 晉元帝 (r. 317-322) called for a re-collecting of texts to restore the imperial libraries after the court had to flee due to pressures from the northwest, Méi Zé submitted a copy of the oldscript recension of the Shàngshū together with the pseudo-Kŏng recension, the Shàngshū Kŏng shì zhuàn 尚書孔氏傳 in 58 chapters. This became the standard version for centuries to come. The Sòng 宋 (960-1279) scholar Wú Yù 吳棫 was the first to raise doubts about it. However, it was not until the Qīng 清 (1644-1911) that it was declared a forgery. Yán Ruòqú in his Gǔ wén Shàngshū shū zhèng 古文尚書疏證) and Huì Dòng 惠棟 (1697-1758) in his Gǔ wén Shàngshū kăo 古文尚書考 were decisive in this.

102 The different textualisations of the fabula as given in "*Wǔwáng jiàn zuò" $A$ and $B$, where King $\mathrm{Wu}$, after fasting for several days, is presented with ancient wisdom as recorded in "Dān shū” (Cinnabar Writings) 丹書 by Shīshàng Fù 師尚父, is a similar case in point. (The text is recorded in the Qinghuá Manuscripts 2008: 149-168. It has been analysed by Krijgsman 2016.) 


\subsubsection{The Three “Fù Yuè zhī mìng”: *shàng}

There is a marked structural difference between "Fù Yuè zhì mìng" *shàng on the one hand, and *zhōng and *xià, on the other. *shàng is a brief retrospective account of Fù Yuè (Yue from the Rocks of Fu) and his relation to Wǔdīng:

1. 1 惟殷王賜說于天, 庸為佚仲使人。

王命厥百工像, 以貨徇求說于邑人。

1. $\left.\quad\right|^{1}$ The King of Yin, [Wǔdīng, ${ }^{103}$ was given from Heaven [the image of] Yuè; [at that time Yuè] served as a conscript labourer in service of Yì Zhòng 佚仲.

The king commanded his craftsmen to make a liking [of that image], and had him searched by among people in the domain for a handsome reward.

$2 A$. 惟射人 $\left.\right|^{2}$ 得說于傅嚴,

厥俾繃弓, 引關辟矢。( ${ }^{\star}{ }_{0} \mathrm{iij}$ )

2A. An archer $\left.\right|^{2}$ tracked Yuè to the rocks of Fù 傅;

he was made to draw his bow; as he was drawing the bow to the full, he prepared his arrows.

2B1. 說方筑城, 縢降庸力, 厥說之狀, 腕 $\beta$ 肩如椎。

2B2. 王乃訊說曰:

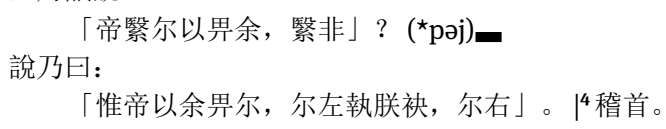

2B1. At that time, Yuè was [conscripted to] pound the city wall, and his body was tied up by use of force; the appearance of Yuè was such that wrist and $\left.\right|^{3}$ shoulders were like a mallet.

2B2. The king asked of Yuè saying:

'Is it you, the Heavenly Dì presented to me? Or is it not you?'

Yuè [, reporting of his dream,] responded:

'It is [indeed] me that the Heavenly Dì presented to you [in your dream]; your left held my sleeve, with you [standing] on the right'. [He thus] $\left.\right|^{4}$ touched his forehead to the ground. The king said: 'indeed, it is so'.

3A. 天乃命說伐佚仲。

3B1. 佚仲氏生子, 生二牡豕。( $\left.{ }^{\star} l a j ?\right)$

3B2. 佚仲卜曰: 「我其殺之? ( ${ }^{\star}$ t 2 ) 我其 $\left.\right|^{5}$ 已, 勿殺? 」

3B3.「勿殺」是吉。

3B4. 佚仲違卜, 乃殺一豕。(`laj? $)$



103 Wǔdīng is the founding king of the Shāng, reigning to c. 1189 BC. 
3D. 一豕随仲之自行, 是為赦俘之戎。

3E. 其惟說邑, 在北海之州, 是惟園土。說 $\left.\right|^{7}$ 來, 自從事于殷。王用命說為公。

3A. Heaven (through Wǔdīng) then commanded Yuè to attack the polity of Yì Zhòng 佚仲.

3B1. At that time, the Clan of Yì Zhòng had given birth to children, two of which grew like pigs.

3B2. Yì Zhòng carried out a divination where he asked [the spirits]: 'Should we indeed kill them? Or must we stop and not kill [them]?'

3B3. [The answer of the spirits was:] 'Not kill' is auspicious'.

3B4. Yì Zhòng disrespected the outcome of the divination and killed one pig nonetheless.

3C. Yuè attacked Yì Zhòng from Yī 部; one pig was so farsighted [that he knew that Yuè would attack Yì Zhòng from Yī 部], and saved [the lord of Yì Zhòng] by helping him flee. As the [city of] Yì Zhòng was annihilated, the people of the city $\left.\right|^{6}$ all followed [Yuè].

3D. The one pig (the one that warned Yì Zhòng) followed [Yì] Zhòng on his travels; [together] they became the Róng tribe of Shè Fú (Pardoned Prisoner) [in the Northwest].

3E. It was now made Yuè's land; it was located at the regions of the Northern Sea, termed the 'Turn Around Soil'. Yuè $\left.\right|^{7}$ returned and started to take care of the affairs at Yìn. On that account the king commanded that Yuè become Gōng. ${ }^{104}$

*shàng contains a limited amount of speech and can be divided into three parts, each narrating one element of Yuè's progression into Wǔding's service. It is headed by a frame, a brief account of how Wǔding came to possess Yuè's image. Then comes the encounter of Wǔdīng and Yuè, presented as a brief dialogue. Third is the account of Yuè's attack on the polity of Yì Zhòng, as well as his consequent elevation to the rank of a Gōng. Structurally, the three parts each consist of 'theme'; 'parenthesis'; 'realisation of the theme'. The 'realisation' entails that action translates the 'theme' into a new manifestation of the matter. In schematic form it looks like this:

104 Note the anachronism of awarding Yuè the first in the five ranks of nobility (gōng) for the period supposedly presented in the text - but not for when the text was likely created. 
1. \{divine afflatus\}:Image of Yuè (theme)
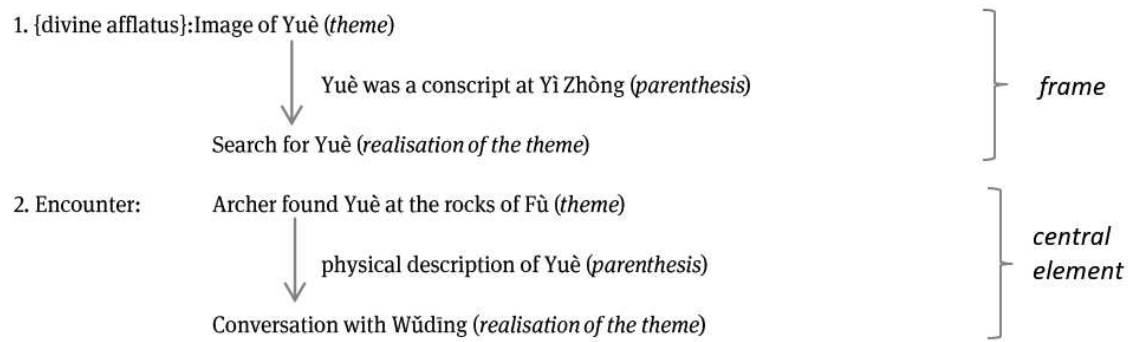

3. Attack: Wǔdīng commands Yuè to attack Yì Zhòng (theme)

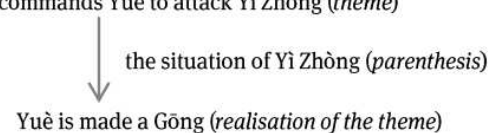

concluding element

Although the skeleton outline sees the basic structure of *shàng as frame; central element; concluding element, of which each is organised along the said pattern of theme; parenthesis; realisation of the theme, this does not mean it has a welldeveloped storyline of the kind one ideally hopes to find in a narrative. The opposite is the case. The three parts of the text do not connect well with one another and there remain obvious gaps. However, despite the poor development of the narrative, the parallel patterns nonetheless serve to present the text's main theme, that is, the encounter of Yuè as summed up in the conversation between him and the king. The encounter-this is the sole element where speech is produced-is notably placed at the centre. Structurally, it is a principal insertion. It stresses in formal terms the encounter of Yuè with Wǔdīng after Wǔdīng had trusted the divine inspiration in which the image of Yuè was presented to him.

This is important because it allows us to situate *shàng both sociopolitically and philosophically. Three things are thus impressed on the recipient. First, the king receives divine inspiration from Heaven about the image of the ideal minister as someone who can aid him in ruling his polity. Second, the king understands the afflatus and translates it into reality by searching for the actual person behind that image. Third, when tested, the person behind the Heavenly inspired image does indeed not disappoint. This is shown by the swift takeover of Yì Zhòng upon the king's command. On the surface level the text praises Yuè for his virtues. In reality it is Wǔding whose virtue becomes manifest thus. This is because Heaven directly interacts with Wǔding, who both comprehends the divine afflatus and, in a threefold manner, responds to it most appropriately - first, by believing in the signs given him by Heaven; second, by translating them into reality through his action; third, by having the Heavenly signs confirmed when testing Yuè. In this way Wǔding is shown as a model ruler - just like divine Yáo. It is through Yuè that the all-encompassing virtue of Wǔding becomes manifest. That a ruler's 
virtue is made manifest through his minister is a common theme in the late Eastern Zhōu Shū and repeatedly discussed in the literature of the Warring States. Wǔding, it becomes clear, is a most keen observer of Heavenly command 天命. As seen in “*Yĩn zhì” before, the authors of *shàng anachronistically project the Eastern Zhōu concept on to the Shāng to make a historically grounded argument. "Fù Yuè zhì mìng” *shàng, in many respects a poorly designed text, nonetheless formulates a powerful claim about ideal rulership because it strikes a chord with its contemporaneous audiences.

\subsection{6 “Fù Yuè zhī mìng” *zhōng}

${ }^{\star} z$ hōng and *xià are basically lists of admonitions addressed to Yuè. They are given to Yuè as he enters into the king's service:

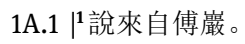

$1 \mathrm{~A} .2$ 在殷, 武丁朝于門。入在宗。王再比厥夢, 曰: 「汝來, 惟帝命。」(^mə-rin-s)

說 $\left.\right|^{2}$ 曰: 「允若是。」( ${ }^{\star} \mathrm{de}$ e?

$\left.1 A .1\right|^{1}$ Yuè returned from the rocks of Fù.

1A.2 At Yīn, (the king) Wǔdīng greeted [him] for an audience at the gate. They entered the temple. [There], the king compared him twice [more] to [the image of his in] his dreams, and said: 'that you came is by command of the [Heavenly] Dì'.

Yuè $\left.\right|^{2}$ responded: 'It is indeed so'.

2A. 武丁曰:

「來格汝說。聽戒朕言, 真之于乃心:

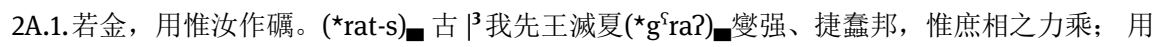

孚自藝。敬之哉！啟乃心, 日沃 $\left.\right|^{4}$ 朕心。

2A.2. 若藥, 汝不瞑眩, 越疾罔疹。朕畜汝, 惟乃腹, 非乃身。

2A.3. 若天旱, 汝作淫雨; $\left({ }^{\star} \mathrm{G}^{\mathrm{w}} \mathrm{a}\right.$ - $\left.-\mathrm{s}\right)$ -

2A.4. $\left.\right|^{5}$ 若滿水, 汝作舟。 ${ }^{\star}$ tu)

汝惟兹。說, 底之于乃心。」( $\left.{ }^{\star} \mathrm{s} \ni \mathrm{m}\right)$

2A. Wǔdīng said:

'Come here, Yuè! Listen, and take as a warning, these words of mine, and place them within your heart:'

2A.1.'Suppose me a weapon of steel; I will use you for a whetstone. 
In days yore, $\beta^{3}$ our former kings extinguished the Xià; [they] attacked the strong, ${ }^{105}$ and gained victory over the wriggling state, for they relied on the strength of the most senior officials among the many [men of a] different [surname]. This was achieved through their high confidence [in the most senior of their advisees]. Revere this! Open your heart-mind and daily irrigate $\left.\right|^{4}$ my heart-mind'.

2A.2.'Suppose me [in need of] medicine! If you don't distress the patient, there will be no overcoming of his sickness! When I nourish you [in return], it is your belly [that I fill], not your person [that I cultivate]'.

2A.3. 'Suppose me [encountering] severe drought! You will serve as heavy rain'.

2A.4. ${ }^{5}$ 'Suppose me [crossing] the ford filled with water, you will serve as [my] boat'.

'This is your [task]! Yuè, place these (my instructions) at the bottom of your heart!'

\section{B.1. 且天出不祥, 不及遠, 在厥落。( $\left.{ }^{\star} k \partial . r^{\complement} a k\right)$ -}

汝克 $\left.\right|^{6}$ 筧視四方, 乃俯視地, 心毁惟備。

\section{敬之哉！用惟多德。( $\left.{ }^{\star} \mathrm{t}^{\uparrow} \mathrm{\partial k}\right)$}

2B.2. 且惟口起戎出差, 惟干戈 $\left.\right|^{7}$ 作疾; 惟愛載病, 惟干戈生厥身。

2B.3. 若訫不視, 用傷。吉, 不吉。余告汝若是。( ${ }^{\star} \mathrm{de}$ ) —歭之于乃心 $\mathbf{L}$ 。

2B.1. 'On the point when Heaven may cause something that is inauspicious, do not place [your actions] in the distant (=do not wait long) but act at its beginnings. You are capable $\left.\right|^{6}$ of fixing the eyes [at the world] and overseeing the four quarters; when looking down, you oversee the earth; take precautions when people carry blame in their heart-mind!

Revere this! Obey this and you will add to your charismatic power!'

2B.2. 'On the point when the mouth gives rise to war and dishonour, it is the weapons of war that $l^{7}$ give rise to suffering; it is grudge that generates illness; it is weapons of war that may cause accident to one self'.

2B.3. 'Should you not discern slander, you will suffer harm. Whether [you consider this] as auspicious or not, it is such that I announce to you! Place it in your heart!'

"Fù Yuè zhī mìng" *zhōng takes as its point of departure the return of Yuè to Yīn. However, as is obvious from the partial reduplication of this in *shàng and ${ }^{\star} z h \bar{n}$, the two texts do not connect seamlessly. ${ }^{106}$ This does not mean they are not related. But the rather crude segue from * shàng to ${ }^{\star} z h o ̄ n g$ might suggest a compositional gap between the two. * shàng and ${ }^{\star} z h \bar{n} g$ dwell on a related theme.

105 Schwartz 2019: 161n. 221 discusses the graph 隻 as meaning 'to attack'.

106 The final sentence of *shàng (3E.) reads 'Yuè $\left.\right|^{7}$ returned and started to take care of affairs at Yīn. On that account the king commanded that Yuè be a Gōng'; the first sentences of * zhōng (in 1A. and 1B.) say ' ${ }^{1}$ Yuè returned from the rocks of Fù 傅. At Yīn, [Wǔdīng greeted [him] for an audience at the gate'. 
But it does not seem they were produced as one organic unit. This 'rupture' is also evident from a change of the narrative perspective. While for the most part the events in *shàng are narrated from a bird's-eye view, distanced in perspective, ${ }^{\star} z$ hōng stays much closer to the events.

*zhōng can be divided into three parts, headed by a frame. The frame stages a scene where Wǔdīng meets Yuè outside the gates, confirming once more the image that was given to him in a dream. (Note that the dream imagery is in *shàng only implicitly through Yuè's account.) After Yuè is confirmed as the person behind the dream image, Wǔding presents a catalogue of admonitions to Yuè, now his loyal minister (2A.1-2A.4). ${ }^{107}$ The text is closed by a formula that is repeated twice, following each set of admonitions.

Because of the repeated closing formula, the two series of admonitions are placed parallel. Each is marked accordingly and framed in a bracket of two formulae, 敬之哉 'revere this', on the opening side, and 底之于乃心 'place it in your heart', on the closing side. The skeleton structure of * $z$ hong can thus be described as follows:

1. Staging the event: Wǔdīng meets Yuè at the gates

1.A1-2exchange where Wǔdīng's vision is being confirmed

2. Admonitions:

2.Aframing the admonitions through a pre-warning announcement

2.A-B two series of admonitions:

2.A: 1: 若 ' $x$ ', then 汝 should ' $y$ '; 敬之哉 'revere this'

2: 若 ' $x$ ', then 汝 should ' $y$ '

3: 若 ' $x$ ', then 汝 should ' $y$ '

4: 若 ' $x$ ', then 汝 should ' $y$ '; 底之于乃心 'place it in your heart'

2.B: 1: 且 ' $x$ ', then ' $y$ '; 敬之哉 'revere this'

2: 且 ' $x$ ', then ' $y$ '

3: 若 ' $x$ ', then ' $y$ '; 歭之于乃心 'place it in your heart'

In * zhōng, the king's admonitions are not closed compositionally - nor are there any frames marking the end of the text. It is conceivable, theoretically, that the text went on with more sets.

107 The admonitions are headed by a speech-immanent frame, 'Wǔdīng said'. 


\subsection{7 “Fù Yuè zhī mìng *xià}

"Fù Yuè zhī mìng" *xià presents another catalogue of admonitions. Just as in *zhōng it contains no structural features closing the text formally, thus leaving the theoretical possibility that it was expandible or contractable according to need:

$\mathrm{X} \quad[\ldots . . .$.

1A. [2] ${ }^{108}$ 云, 經德配天, 余罔有擇言, 小臣罔俊在朕服。

1B.1. 余惟命汝說庸朕命 ${ }^{109}$ 。

$1 B .2$ 余柔遠 $\left.\right|^{[3]}$ 能雨, 以益視事, 怩永延 (`lan) 一 助余一人。”

[...]

1A. $\left.\right|^{[2]}$ it is said, "in penetrating charismatic power, [I] correspond with Heaven", [but] I never had occasion to make choice of my words, for among my petty ministers, I never had in my service a man of talent'.

1B.1. 'It now is my command to you, Yuè, that you carry out my commands:'

1B.2. 'I [command that you] "be kind to those afar and $\left.\right|^{[3]}$ draw on those that are near", that the oversight of [governmental] affairs will bring benefit; your assistance shall endure - support me, the one person!'

2A. 王曰: “說! 既亦視乃服。勿易, 俾越:

2A.1.如飛雀, $\left.\right|^{[4]}$ 罔畏羅, 不惟鷹, 惟乃弗虞民, 厥其禍亦羅于㝓䍖 -”。

2A. The king said: 'Yuè! Now that you have arrived in your position, I shall scrutinise your service. Do not take this lightly (with the result) that things get worse:

2A.1.You are like a small sparrow ${ }^{[4]}$ with no fear of being caught; [you] are not an eagle. Be untroubled by the common folk, for their misfortune will be caught in the net [like the eagle]'.

2B. 王曰: “說！汝冊狂曰: 余克享 $\left.\right|^{[5]}$ 于朕辟。

2B.1. 其有乃司四方民丕克, 汝惟有萬壽, (`duP-s) 一在乃政; ( ${ }^{\star}$ ten-s)

108 The editors of Qinghuá Manuscripts claim that the first slip of *xià is missing. While it is obvious that the text is missing its initial portion, I do not think it is obvious how many slips are missing. I therefore put the slip numbers in brackets to indicate doubt about their precise number.

109 The editors of Qinghuá Manuscripts transcribe graph 2/23 as 幛 (融) which they read as 'clear'. A justification is not provided, but it is clear that they base their reading on a similar use in the Zuǒ zhuàn. Huáng Jié glosses róng 融 (`lun) as yōng 庸 (`lon) ‘to use, employ; obey’. He draws a parallel to the “Yáo diăn” which reads 汝能庸命, 巽朕位 (you can carry out my commands - I will resign my place to you). 
2B.2. 汝亦惟克顯天恫瘝小 ${ }^{[6]}$ 民，中乃罰;

2B.3 汝亦惟有萬福業業, 在乃服。( $\left.{ }^{\star} b ə ?\right)$-”

2B. The king said: 'Yuè! Do not recklessly ask: "how would I be capable to give $\left.\right|^{[5]}$ to my lord".

2B.1. Indeed, in managing the commonfolks in the four quarters of the world, you shall make them greatly capable, and you have myriad years in governing'.

2B.2. 'You shall indeed be able to make manifest Heaven in making the pains of the petty ${ }^{[6]}{ }^{[0 m-}$ monfolks [those of] your own that your punishments be precise';

2B.3.'You shall indeed have manifold blessings in your service to me!'

2C. 王曰: “說! ( ${ }^{\star}$ lot-s) 一書, 汝視日; 夜, 汝視辰。是罔非乃 $\left.\right|^{[7]}$ 載。 敬之哉! 若賈, 汝冊非貨如哉石。( ${ }^{\star}$ dak)

2C. The king said: 'Yuè! In daylight you shall observe the sun; at night you shall observe the stars. Of those, not any is not your ${ }^{[7]}$ burden!

Revere this! Be like a merchant, you shall not mistake valuable goods for a muddy stone'.

2D. 王曰: “說! 余既諟劼枈汝, 思若玉冰, 上下目不我 $\left.\right|^{[8]}$ 義(儀)。( $\left.{ }^{\star} n a j\right)$-”

2D. The king said: 'Yuè! I have already warned and cautioned you that your thoughts be pure as jade and ice that on above and below there shall be none who does not take us as their ${ }^{[8]}$ model'.

2E. 王曰: “說！ (lot-s) 一昔在大戊, 克進五祀, 天章之用九德, 弗易百姓。( ${ }^{\star}$ sen-s)

$2 \mathrm{E} .1$ 惟是, 大戊謙曰: ‘余不克 ${ }^{[9]}$ 辟萬民, 余罔墜天休。乃惟三德賜我, ( ${ }^{\star}{ }^{\Upsilon}{ }^{\Upsilon} \mathrm{aj}$ ? $)$ 一吾乃敷之于 百姓。( ${ }^{\star}$ sen-s) 一余惟弗雍天之嘏命。”

2E. The king said: 'Yuè! In days of yore under Dà Wù, he was capable to promote the "five types of offerings"; Heaven made manifest this through the "nine virtues"; [he] would not take lightly the [commonfolks of the] hundred surnames'.

2E.1. 'In this way, Dà Wù modestly said: "I am not capable to serve as $\mid{ }^{[9]}$ lord of the myriad folks! I shall not let drop Heaven's grace”. And so it was that the 'three virtues' were bestowed upon me that I disperse them on the hundred surnames. I shall not obstruct Heaven's great command!'

2F. | [10]王曰: “說！冊獨乃心, 敷之于朕政, (`ten-s) 一裕汝其有友, 正朕命哉。 L”

2F. $\left.\quad\right|^{[10]}$ The king said: 'Yuè! Do not keep a solitary heart-mind but disperse it widely in governmental service to me. Be wealthy in counting your companions, that they may correct my commands!'

Parallel to ${ }^{\star} z h \bar{n} g,{ }^{\star} x i a ̀$ places the admonitions in a narrative setting. While in ${ }^{\star} z$ hong they are framed by a stage-like dramatisation of the event, as far as one can tell from the manuscript at hand, *xià simply contextualises the catalogue by 
a brief statement put into the mouth of Wǔding. All admonitions relate to governmental affairs. ${ }^{110}$

In *xià each of the six admonitions is marked consistently in the form 'the king said: “Yuè! Xxx”” (王曰: 說! xxx). While in *zhōng the king spoke to Yuè through similes and metaphors, in *xià his admonitions are for the most part explicit and related to rule. Yuè ought to be untroubled by the people and should not think of them as a threat; he ought to be precise in his punishments and make manifest Heaven's will through his service to Wǔding; he is responsible for everthing without restriction; he must make Wǔdīng and himself pure as jade, so they become a model for the people; Yuè is to make government affairs his entire obligation.

\subsection{Text Stability and Warring States Thinking}

Not one of the three entities collected under "Fù Yuè zhì mìng" presents a conclusive text. Despite the clear skeleton structure, *shàng nonetheless contains some obvious gaps in the narrative; in *zhōng and *xià, although they too were clearly structured, their parallel admonitions remain open ended.

This differs markedly from the pseudo-Kǒng old-script "Yuè mìng”. Ritually burdened with anxiety that he may not be a good enough successor in the line of his predecessors of virtuous rulers, the transmitted "Yuè mìng" describes in vivid ways how the king refuses to speak for years, until he dreams of Yuè as someone who might implement his rule. Against that narrative, the first of the transmitted triplets presents a set of admonitions that resemble those pronounced in the manuscript text *shàng. Yuè then gives a speech of agreement in response to his king, closing the received triplet. As Yuè is accepted in the service of Wǔding, the second of the received triplets presents a long-winded speech where Yuè addresses Wǔding by expounding a minister's right behaviour. The king responds with excitement to Yuè's speech. Accepting his words, Yuè once more stresses his role in serving the king. In the third transmitted triplet, Wǔdīng tells Yuè of his past experience, which he now uses to formulate a claim about their bright future. When acting together, he concludes, they will serve as paragons of virtue. Yuè responds to this by formulating the principles on which ministers ought to serve their rulers. Wǔding adds a further note to it and Yuè pays obeisance. The final triplet

110 Since at least the initial slip is missing, nothing can be said with certainty about framing devices in "Fù Yuè zhī mìng" *xià. 
then closes with Yuè's words: 'I will venture to respond to, and display to the world, your Majesty’s excellent charge’ 敢對揚天子之休命.

The old-script text portrays Wǔding and Yuè as the perfect match for ideal rule. In a seamless progression from shàng to xià, it provides a compelling account of a wise king appointing an astute minister to make the king's rule longlasting. In contrast, the three manuscript texts are a far cry from such a complete narrative, with Yuè hardly given at voice at all. While the transmitted "Yuè mìng" has developed-or more likely, was reinvented-as one text in three parts, its coherence is lacking in the manuscript texts. The manuscript texts each dwell on a particular aspect of the fabula of Wǔding and Fù Yuè but hardly comprise one larger, self-consistent, narrative. It is therefore possible that they are each independent renditions of selected aspects of a more widely known fabula, responding to what was considered relevant to a certain social grouping in their particular circumstances, not one text in three parts. Put to the brush at the same workshop, this does not conflict with the fact that they are written on slips of the same making and collected under one common designation.

While the manuscript texts lack a uniform narrative, they are typical representatives of Warring States thinking. * shàng and * zhōng portray a king who understands the signs given to him by Heaven. They present a ruler who is attuned to Heaven, responding to it in the right way. The kings of *shàng and *zhōng are capable of translating Heavenly command 天命 into virtuous rule through Yuè. This is taken up again in *xià.

Nothing of the above is unique to the fabula of Wǔding and Yuè, let alone Shū genre. Manuscript texts such as Qīnghuá “Zhōu Wǔ Wáng yǒu jî” (Ch. 5) or Guōdiàn “^Qióng dá yǐ shî” 窮達以時 (Success and Failure Depend on Their Time), to name but two of the more obvious examples, dwell on similar themes too. ${ }^{111}$ In "Zhōu Wǔ Wáng yǒu jî" Heaven intervenes at the point when King Cheng misses the true intentions of the Duke of Zhou in serving the house of Zhōu; the argument-based text “^Qióng dá yǐ shí” describes the manner in which wise ministers of the past were understood, and then received appointment, by ancient rulers. ${ }^{112}$ The Yuè figure of "Fù Yuè zhī mìng" displays his ability by aiding Wǔding to translate Heavenly command into good rule. It thus connects to a ubiquitous theme of Warring States thinking, which celebrates a ruler's virtues that enable him to choose the right man.

111 For “Qióng dá yǐ shî” see Meyer 2011: Ch. 2. A full translation is also given in S. Cook 2012.

112 The common theme expands into the humble past of the wise ministers before their appointment. The same is true in the case of Yuè, a conscript labour building the city walls of Yì Zhòng. 


\subsection{Manuscript Cultures and the Literarisation of Shū Traditions}

To produce a manuscript is a separate thing from producing a text. Equally, to compose a text and writing it down are different activies. Texts of antiquity are the creation of a meaning community, with anonymous authors working in a stream of traditions. The written manifestation of a text is therefore the product of writers. While they may coincide, author and writer are generally different people. Hence it is not surprising that we find different instantiations of a text in different physical form.

Consider again "Zīyì". The Guōdiàn representation of it materialised on slips of 32.5 centimetres, tapered towards both ends. The Shànghăi manifestation was copied on much longer slips, 54.3 centimetres in length, cut evenly at both ends. ${ }^{113}$ The calligraphy is different enough to be sure that dissimilar hands applied the writing. Or take what much later becomes known as "Lăož”". In the corpus of the Guōdiàn manuscripts it is produced on three separate bundles of different making. ${ }^{114}$ Here too, it is clear that different hands applied the writing. It is also not uncommon to find groups of texts written on slips of the same making

113 Guōdiàn "Zīyī" is written on forty-seven slips. The slips are extremely well preserved, with not a single one in a fragmentary condition. They were connected by two cords, 12.8-13 centimetres apart. (See Guōdiàn Manuscripts 1998: 129) The Shànghaǐ manuscript is on twenty-four slips, of which only eight remain intact. Originally, three cords connected the slips in the manuscript. (See Mă Chéngyuán 2001-, 1:43-68, 169-213) It goes without saying that the calligraphy shows characteristics of different hands.

114 Bundle A (jiă 甲) consists of slips, 32.3 centimetres in length if not broken. The altogether thirty-nine slips are tapered towards both ends. Judging from the marks on the slips, they were connected by two cords, about 13 centimetres apart; the eighteen slips of bundle B (y乞 乙) are about 30.6 centimetres in length, and they are cut even on both sides. Two cords, 13 centimetres apart, connected the strips; the unbroken slips of bundle C (bing 丙) measure only c. 26.5 centimetres. The twenty-eight slips of bundle $C$ were connected by two cords, 10.8 centimetres apart. Next to what later hardens into "Lǎož̀", they also carry a text, now called “`Tài yī shēng shǔ̌ 太 一生水 (The Ultimate One Generates Water). See Guōdiàn Manuscripts 1998: 111, 123-126. The calligraphy on the three bundles was applied by different hands. For a review of scholarship on the “^Tài yī shēng shư̌”, see Chén Lìguĩ 2005. The Guōdiàn materials cover about three-fifths of what later becomes known as "Lǎož̀". While the materials 'resemble the transmitted Lăož closely in spirit and tone', they clearly differ from the transmitted text in style and content. (Meyer 2011: 209) A division of the materials into a dào 道-part (The Way) and a dé 德- part (Power) is not even vaguely present. Methodologically the Guōdiàn materials should therefore not be considered as "Lǎož”". As William Boltz put it in 1999: 596, we should beware of labelling a late fourth-century BC manuscript 'with a name for which our first evidence is a century or more later'. See further Perkins 2015. 
and collected in one manuscript bundle. Again, the finds from Guōdiàn are a good example. The corpus contains a total of six groups of slips that are clearly distinct in physical terms. But these six manuscript groups carry at least eighteen different texts, ${ }^{115}$ perhaps more, depending on how one separates them. ${ }^{116}$ Shànghǎi and Qīnghuá confirm this picture. ${ }^{117}$

When manuscript and text production are separate activities, as they were in the Warring States, and when texts and manuscripts are produced on a scale significantly larger than the single occurrence of one text on one manuscript, then we must assume that the manuscripts, or at least their basic constituents-bamboo slips-were a commodity at the time. The image of the individual scholar, equipped with knife and brush, producing his own copy of a text, does not hold as a general model for text transmission at such a time. ${ }^{118}$ Bamboo slips had to be prepared for the use as writing material. They had to be cut, dried, and then transported to wherever demand was high. This must have been an industry in itself, with division of labour a likely scenario. Today the back of a manuscript provides a little window into that world of trade in bamboo slips. Now that good photographs of these artefacts are available-a situation that was not true of Guōdiàn and Shànghǎi where only the front of the slips was photographed-we find that many manuscripts have on their back a thin slanting line. Its exact purpose is as yet unclear. It has been suggested that it was used to indicate the order of the

115 This number follows the conservative text reproduction of the editors of Guōdiàn Manuscripts.

116 Altogether, the tomb corpus of Guōdiàn contains 804 bamboo strips, of which 730 are inscribed. They carry some 13,000 characters. While for the most part the calligraphy has obvious Chǔ characteristics, the writing was applied by multiple hands. Six groups of manuscripts comprise first: slips that are 32.3-32.5 centimetres in length; second: slips of 30.6 centimetres length; third: slips that measure between 28.1 and 28.3 centimetres; fourth: slips of around 26.4-26.5 centimetres length; the fifth and sixth groups contain decidedly shorter slips, namely 17.2-17.5 and 15.1-15.2 centimetres length.

117 Such multi-text manuscripts are common to manuscript cultures across the globe. The Măwángdui silk manuscript is just one example showing that in China this practice is not a Warring States phenomenon.

118 These conclusions tie in with remarks made by Christoph Harbsmeier 1999: 222 in his study of the authorial presence in pre-Buddhist texts from China where he states:

'Traditionally, there was a division of labour in ancient China between the person who uses the knife or the brush to inscribe texts on various materials and the person who creates the texts that specialists in writing write down. Writing was originally a specialised craft and it remained a menial, often an anonymous task. The function of the editor/compiler was separate from that of the person responsible for the production of a given inscribed material object.' 
slips. ${ }^{119}$ However, cases such as Qīnghuá “Zhōu Wǔ Wáng yǒu jî”, which also carry slip numbers on the back, seem to speak against this hypothesis - unless of course we assume that the slanting lines served this purpose at different stages of manuscript production. ${ }^{120}$

To me the most plausible scenario is to divorce the purpose of the slanting line from the actual production of the manuscript and link it to the production of the raw material of the manuscript instead - the bamboo slips. It is revealing therefore that whenever a manuscript contains both a slanting line and slip numbers, the two correlate. ${ }^{121}$

Consider Qīnghuá “Zhōu Wǔ Wáng yǒu jỉ”. Here, as in most cases, the slanting line-in some texts it is as thin as a hair-is carved into the back of the slips with a very sharp tool. But lines drawn in ink exist too. ${ }^{122}$ In the vast majority of cases, the slanting line extends down to the second binding strap. ${ }^{123}$ Cases where the line continues beneath the straps further indicate that the slanting line was imposed on the bamboo slips before they were bound into a manuscript. The current hypothesis, shared by both Sūn Pèiyáng and the editors of the Běi Dà (Peking University) Western Hàn-Lăož̆, is that the slips of one manuscript all come from the same bamboo tube, and the slanting line was carved into the tube before the slips were cut from it. ${ }^{124}$ This shows how little waste was produced in the making of the slips. Moreover, it shows that the line was a good indicator of which slips

119 Staack 2012: 8-13.

120 Stryjewska 2013: 7.

121 This observation coincides with Hán Wēi 2012.

122 They include manuscripts in the Bāoshān 包山 and Qīnghuá collections. See Sùn Pèiyáng 2011 and 2012.

123 The recently purchased Běijīng Dàxué 北京大學 Western Hàn “Lǎozǐ” manuscripts shàng 上- and xià jīng 下經 cast further light on the purpose of the slanting line on the back of the slips. This corpus is consistent in that the slanting line-as is true of the Qīnghuá "Zhōu Wǔ Wáng yǒu ji”--runs exclusively from the top left of the first slip to the upper half of the right end of the final slip. According to Sūn Pèiyáng 2011: 449-462, this situation applies to the great majority of bamboo manuscripts from the Warring States to the Hàn. A counter example is given in the Qiinghuá “`Qí yè” 耆夜 manuscript where the slanting line also goes in the opposite direction. This suggests that a minority of manuscripts also had a 'V'-shaped, or perhaps 'W'-shaped line on the back of the slips instead of just the diagonal '/' that applies to the majority of cases known thus far.

124 Sūn Pèiyáng 2011: 449-462; Běijīng Dàxué cáng Xīhàn zhúshū, vol. 2: 227-235. Note that Xíng Wén 2016a and 2016b considers the Běi Dà Western Hàn-Lăož a forgery. However, his study was poorly executed and carries no conviction. Christopher Foster 2017 has produced a comprehensive refutation of Xíng's argument. 
belong together and in what order they should be placed - a useful aspect now as in antiquity.

To apply the slanting line therefore greatly helped transporting bamboo slips en masse to whatever place they were needed - without confusing the materials with one another. It also suggests that the numbering on the back of the slips, as it occurred, mainly aided the act of writing a text-possibly for determining the length of the copy-rather than the binding of the manuscript, for which the slanting line probably served as primary reference. ${ }^{125}$ “`Yinn zhì”, with its unusual positioning of the slip sequence-numbers, supports this hypothesis.

The sequence of producing the manuscript text “*Y̌n zhì” was likely as follows: first, apply the numbers on the back of the slips; second, bind them into one manuscript; third, copy the text on to them. The uneven positioning of the numbers, it seems, was not an obstacle to correct placing. The sequence-numbers, disconnected from the binding of the slips into the manuscript, served as a guideline for the writer of the text. The writer, it therefore seems, must have had a good estimate of the physical length of the text he was about to produce. This suggests he was working from a written Vorlage. ${ }^{126}$

The above observations, showing the complex processes of producing the slips for writing, point to the division of labour at the various stages of making the actual manuscript. This confirms there was sufficient demand for this product, or else such forms of sophistication would not need to develop in the first place. And of course, other types of writing such as administrative or hemerological equally required the material support of bamboo slips, not just the literary texts. The material evidence thus throws into sharper relief the degree of welldeveloped literary cultures during the Warring States. The elaborate production of stationery developed parallel to the intellectual environment where written texts were composed to a sometimes-sophisticated standard. This comes as no surprise. The two phenomena normally appear in tandem - not just in China but across early literate societies more generally.

Although the length of a text remains mostly relatively short, ${ }^{127}$ there is a clear increase in texts that develop a complex narrative. "Zhōu Wǔ Wáng yǒu jí” and

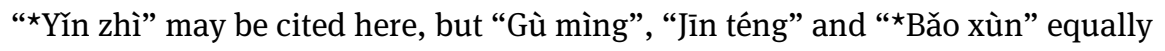
make that point. That some texts are composed to a much lower standard only

125 The fact that not all manuscripts have that line only confirms manuscript production at a considerable scale and in different centres.

126 Note that this does not imply exact reproduction. See the discussion on pp. 66-67.

127 Wagner 1999. 
confirms the diffusion of writing well beyond the centres of power and learning. "Fù Yuè zhī mìng" shows this.

\subsubsection{Texts and Designations}

Following on from this it is clear that we must beware of drawing direct conclusions about texts and their relationship to one another purely on the basis of their material representation. ${ }^{128}$ "Fù Yuè zhī mìng" suggests that this even applies to manuscripts which are called by the same name.

However, there is an important difference between the designation of a manuscript and the title of a text. The designation of a manuscript facilitates that it be physically accessible; a text title is more complex. It identifies a narrative, or a compositional form, and relates it to a particular text, which has stabilised in a recognisable form. (This does, however, not mean the different text witnesses must be identical.) The reference to a fabula, finally, recognises the relationship of any number of texts to a known fabula.

Take "Zìyi”. Although it shows some flexibility with regard to its actual lexicon, the compositional form of it is entirely consistent in the two manuscript texts known today. This includes the internal composition of the various units of thought, their place in the text, as well as their number. Moreover, the text was physically closed by adding the phrase èrshi yǒu sān二十又(有)三 (23) at the end. “Zīyī” illustrates well how physical evidence points to a well-developed literary culture: despite some flexibility in the lexicon it is a conceptually 'closed' text. It travelled stably from one physical environment to another, and thus, potentially, between conceptual groupings. ${ }^{129}$

“Zhōu Wǔ Wáng yǒu jî" (Ch. 5) is different. Despite the obvious changes in how "Zhōu Wǔ Wáng yǒu jî" and the transmitted "Jīn téng are presented-this relates to different socio-material contexts in which these texts played a roletheir constants show a narrative with high recall value for even contrasting communities. The manuscript has on the back of its final slip the following line: 周武

128 Note that I do not here speak about representational texts. As is true of European late Antiquity, in China too representational texts, that is, texts which captivate the beholder by their material beauty (or wealth) and produced primarily for display purposes, more often than not are of a lower quality of text 'accuracy'.

129 Note that 'text-closure' may just relate to the closure of a text by certain communities or at a given point in time. "Zìyì" is again revealing. While the manuscript versions show that it was considered final by some communities during the Warring States, the transmitted version of the text shows that this was not accepted across time. 
王又(有)疾周公所自以式(代)王之志 “The record of the Duke of Zhou putting himself forward in the place of the king when King Wu was suffering from illness". This reference goes well beyond the customs of denoting the physical item of a manuscript by its contents or the first few words of the text. Making it physically available was arguably not its main objective. Rather, by foregrounding a central notion of the narrative without giving away too much it is indicative of a text title.

For much of the text, the narrative in "Zhōu Wǔ Wáng yǒu jî" focalises exclusively on the events from a horizontal perspective. The effect of this is that we are led to doubt the Duke of Zhou's integrity, up to the point where the king opens the metal-bound casket, realising that the duke had acted in good faith. In this manner, the text gives form to a group's celebration of unbroken loyalty between ruler and subject - also (and perhaps especially?) in moments of distress. The text's strategy to make its audiences relive the king's epiphany when the king is taking the duke's text out of the casket makes manifest the level of sophistication which text composition and text reception can achieve during of the Warring States. Thus, while the reference written on the back of the final slip informs the recipient about the contents of the text, it does not disclose enough to compromise the dramatic features of "Zhōu Wǔ Wáng yǒu jî", which prove so vital for its performative nature.

And what about "Fù Yuè zhì mìng"? The gaps in the textual presentation are so significant that I think it unlikely that the designations of each bundle are the titles of one text in three parts. However, as they are also not acknowledging the material representation of a story, it seems best to explain them as the generic references to a known fabula. While clearly informing the production of these texts, it was worked into different narratives, collected under a single reference. With different communities producing different stories from a common fabula, it is conceivable that more such renderings exist.

In consideration, a highly sophisticated literary culture emerges before our eyes: the diffusion of texts; the occasional identification of a text by title; the literalisation of old cultural capital; the occasional stabilising of a text into a closed entity, paired with the clear signs of the commodification of the writing materials; but also the distribution of texts of a lower quality - this all points to the development of complex manuscript cultures.

\subsection{Reading Shū}

No matter their degree of sophistication, it would be premature to conclude that the texts were all read in a manner similar to the common reading practices today. Certainly of the Shū there is good reason to assume that they were not entirely 
disassociated from oral delivery - at least as far the rhetorical fabric of self-representation of some of these texts is concerned. Warring States textualisations of Shū overwhelmingly show dramatic features. Even the more literary pieces are thus suitably delivered to their audiences, possibly the aristocratic elites, that is, the 'public' of those days. ${ }^{130}$ Markers of dramatic makeup include the discernible use of personal pronouns that we see in nearly all texts discussed in this book; their stage-like openings or closures by means of various framing techniques; the sometimes compelling phonetic texture; the focus on the sometimes intimate exchange between between two actors; their setting in well-described environments, often the royal court; the extended event as developed in them.

But also the physical manuscripts point in this direction. The pronounced use of punctuation marks as seen in some manuscripts is a case in point. Two types are particularly relevant here. Perspective markers, as I call them; and markers of, possibly, breath groups. “`Yĩn zhì” and “Zhōu Wǔ Wáng yǒu jí”, discussed earlier, serve as examples respectively, each showing markings that facilitate the reading of the text out aloud. While in "^Yĩn zhì" they indicate shifts between actors, settings, and perspective, in "Zhōu Wǔ Wáng yǒu jî" they consistently mark up those breaks between chunks of text that are less easily discerned, thus making it more important to signal them when presenting the text to an audience. ${ }^{131}$ While we saw that Shū genre is sustained by the manuscript cultures of the Warring States with the accompanying growing literary sophistication, the spoken and the written word nonetheless continuously complement each other.

130 Text-based performance in early China certainly took a different route from its various counterparts in the Mediterranean world. The Greek tragedy, perhaps the most important representative of texts for performance in European antiquity, was acted out on stage. Sung by the chorus (khorós Хopós) it had as its audience the free men of the polis, and we should expect nothing of this sort when thinking about the performance of texts during the Eastern Zhōu period. (On the origins of Greek theatre, see the collected essays, ed. Csapo and Miller 2007. For a cultural history of the theatre in Greece and Rome, see the collection of articles in McDonald and Walton 2007; Revermann 2017.)

Note in this context that we cannot dismiss the possibility, given the degree of textual sophistication we have seen, that Warring States text producers were capable of creating primarily written materials that nonetheless showed dramatic features.

131 On interpunctuation see the important discussion in Krijgsman 2018. See furthermore, highly illuminative, Mèng Yuèlóng 2017 and Shaughnessy 2017. 


\subsection{Writing Shū}

Before closing, I want to complicate the picture of Shū thus gained. Shū genre describes the written presentation of a repertoire of steady components in an archaic speech register, often used in a setting that was not entirely disconnected from oral delivery. The Shū genre was therefore not primarily constituted by texts but by items of a community's cultural capital that were used in a modular fashion. Its source is not entirely clear, but the ritual and ceremonial language preserved in the thick tradition of Western Zhou bronze texts and the sociomaterial fabric of appointment observances is a most likely candidate - a hypothesis that is sanctioned by the neat overlap between "Wén Hóu zhī mìng" and the "Máogōng-ding".

Facilitated by maturing manuscript cultures where information flowed better, it became increasingly common for sub-groups of the wider meaning community to entextualise select items of the widely shared cultural capital when making a new argument. As a result, with the increasing physical availability of written sources during the Warring States, moulds of text production are beginning to stabilise, and textual patterns of signification increasingly reappear in different texts. With old cultural capital thus woven into new problem space it is only natural that layered texts occurred that develop an extended event even over the short span of just a few hundred graphs or less. Producing a short but stand-alone argument such as "^Y̌n zhì”, one can easily see how it might develop a modular application and reappear elsewhere as a 'unit of thought' in other, more complex, narratives. This would explain a highly layered text such as "Gù mìng”, which as an argument works best when read in conjunction with "Kāng Wáng zhī gào” 康 王之誥, the text directly following it in the Hàn-era recension.

With the narrativisation of cultural capital in maturing manuscript cultures also comes its literalisation. The texts are not just becoming increasingly complex. They become literature, increasingly compelling in the ways they make their point, even if they were initially intended for use by a limited audience of insiders only. "Zhōu Wǔ Wáng yǒu jị" with its quite sophisticated arc of suspense is a case in point.

Still, despite such pushes towards repeated formulations, stabilising text clusters, and even the literalisation of a 'historical' event, the picture gained from the Qinghuá manuscripts is overwhelmingly that of text fluidity, not stability, let alone fixity. However, there are exceptions to this. Of these most striking is “*Mìng xùn” 命訓. 


\subsection{0 “*Mìng xùn” 命訓}

"^Mìng xùn" (Commands and admonishments), with which I close, is collected in volume 5 of the Qinghuá Manuscripts. It is produced on 15 bamboo slips, on the average $49 \mathrm{~cm}$ long and cut evenly at both ends. Three cords were used to connect the slips. Even though the vast majority of slips are incomplete, most graphs are still legible. ${ }^{132}$

Except for the final slip, 15, all slips were numbered in consecutive order at their back. ${ }^{133}$ This makes it easy to confirm its continuous reading.

But not just the material properties of the manuscript facilitate our reconstruction of the text. "^ Ming xùn" has moreover a stunningly close counterpart in “Mìng xùn” jiě 命訓解, a chapter of the Yì Zhōushū ${ }^{134}$ The Qinghuá editors used it to refer to the manuscript text.

The editors chose to take the manuscript text “^Mìng xùn” as a 'shàn běn' 善 本, that is, a 'reliable source text' (sometimes also translated as 'good edition'). This means it allows them to alter-in their thinking, 'correct'-the reading of $Y \hat{\imath}$ Zhōushü "Mìng xùn" jiě, an admittedly complex, and partly certainly corrupt, text. However, I do not think it useful to think of "^Mìng xùn" in those terms, as it would grant undue prevalence to a manuscript text of which we possess only one copy. Even though it reads much better than its counterpart in the Yì Zhōushū, I do not want to exclude the possibility that the manuscript text is just another rendering of a surprisingly stable text at its core with nonetheless loose ends at its fringes. "^Mìng xùn” was certainly a stable text. But it was not static.

132 Slip 1 has its top broken, with one graph missing, its tail is intact; slip 2 has the top broken, presumably two graphs are missing. Its tail is sliced with the crack going through three graphs but no losses; slip 3 has its top broken, with one graph missing, its tail is intact; slip 4 has its top broken, but no graph is missing and its tail is intact; slip 5 has its top and tail broken but no graphs missing; slip 7 has its top broken but no graph missing. Its tale is broken with one graph missing; slip 8 has its top broken but no graph is missing, its tail is intact; slip 9 has its top broken but no graph is missing. Its tail is broken but no graph is missing; slip 11 has its top broken but no graph is missing, its tail is intact; slip 12 has its top broken but no graph is missing, its tail is broken with c. three graph missing; slip 13 has its top broken but no graph is missing, its tail is intact; slip 14 has its top broken with c. two graph missing. Its tail is intact but the slip is broken in the middle, with c. two graphs missing; slip 15 has its top broken, with c. two graphs missing, its tail is intact. Slips 6,10 are fully intact.

133 Numbers 4 and 14 are no longer fully visible.

134 Yì Zhōushū huìjiào jí zhù, juăn 1, Ch. 2: 20-40. 


\subsection{Dialectics of Rule: The Political Philosophy of "* Mìng xùn"}

"^Mìng xùn” is not an easy text. It is therefore all the more surprising how extraordinarily stable it was over the millennia. It develops a rather complex philosophy of rule wherein political power is produced, and reinforced, dialectially from the large to the small and vice versa.

This works as follows. In the political philosophy of "^Mìng xùn” Heaven is the constant reference point. It 'gives birth to the commonfolks' (min), as well as 'accomplishes the Great Command' (dà ming 大命), hence the first line of the text. ${ }^{135}$ This statement is not as innocent as it may seem because, as developed later on in the text, the two-the commonfolks and the Great Command-continuously depend on each other, one serving as foundation of the other - and together they form the basis of a complex system of rule and daily rulings. Justified by Heaven, the Great Command thus governs the workings of the virtuous powers (dé) of the ruler; it corrects the commonfolks through fortunes and misfortunes; it confirms brilliant kings through admonitions. ${ }^{136}$ Then, with the Great Command being 'constant' (cháng 常), the small commands (viz., commands of common orders and rules) are accomplished on a daily basis. ${ }^{137}$ This being so, respect for the system is established in its use on a daily basis and thus, retrospectively as it proves successful, the Great Command-this is now defined as the system of rule and successful ruling-will expand. ${ }^{138}$ As the Great Command expands it further reinforces respect for the Commands, great and small (viz., the Great Command as reinforced through the small commands of daily routines), which in turn serves again as a standard against which the system of rule and its daily rulings are being defined and measured. ${ }^{139}$ And so on.

Thus is the thinking of "^Mìng xùn" as developed in its first building block. The further explorations into the finer details of the dialectics of successful ruling all relate back to this initial unit of thought with its core concepts, which forms the basis of the further philosophical cogitating of the text. From here the various points of departure are developed in matryoshka-esque fashion. While "^ Mìng xùn" considers matters as diverse as what is right (yi); reward and punishments;

$1351 / 1-6 . \backslash^{1}[]$ ( 天?)生民而成大命 $=($ ， )

136 1/7-18. (命)司息 (德), 正以福禍)福, 立明王以您 (訓)之。

$1371 / 20-27$. 大命又(有) 甞 (常), 少(小)命日 $=$ 成 $=$ 。(日成)則敬,

$1381 / 28-33$. 又(有)尚(常)則茎 (廣) $=$,

139 1/34-2/1. (廣)以敬命, 則底 (度)| $\left.\right|^{2}[][[]$ (至于?) 亟 (極)。 
fortunes and misfortunes; fame and shame; loyalty and trustworthiness; pleasure and fear; war and peace; they all remain within a defined system of a dialectics of rule, as prepared in the first few lines. Over the relatively short space of

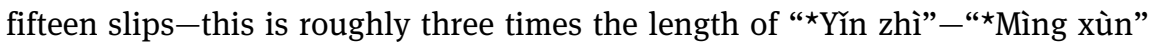
thus develops a scheme, which, in a constant movement between matters small and great, defines a philosophical standard that constantly tests itself dialectically so that it never ossifies into doctrine. “^Mìng xùn” therefore only works as long as the system it develops is constantly questioning itself philosophically and not taken as a paradigm for its own sake.

\subsection{Writing Shū - again}

I shall not provide a full discussion of “^Mìng xùn” at this instant. This would go far beyond the point I am trying to establish here. ${ }^{140}$ Here suffice it to say that the first unit of thought is fully consistent in the two texts, even down to the level of precise wording. This level of consistency is, however, not upheld throughout. It breaks down in the next building block as the transmitted text diverts from the train of thought in the middle of the line. Consider the following in "^Mìng xùn":

夫司㥁 $($ 德)司義而易 $($ 賜 $)$ 之福 $=,($ 福 $)$ 祿才 $($ 在 $)$ 人 $=,($ 人)能居女 $($ 如 $)$ 不居而圣 $($ 重 $)$ 義則尾 (度)至于亟 (極)

Generally speaking, when one is overseeing virtuous power, as well as what is right (yi), and the riches and fortunes are bestowed on men (rén), [so] men can enjoy [such] riches and fortunes, then men (rén) are capable of setting [in them] as if they weren't settling; thus valuing what is right, the standards reach their apex..$^{141}$

As against “Mìng xùn” jiě:

夫司德司義而賜之福祿, 福祿在人, 能無懲乎? 若懲而悔過, 則度至于極。

Generally speaking, when one is overseeing virtuous power, as well as what is right (yi), and the riches and fortunes are bestowed on men (rén), are they not capable of being chastised? If they can be chastised and [thus] repent their wrongdoings, then standards reach their apex. ${ }^{142}$

140 A full translation of the text, together with a philological discussion, is given in Shaughnessy 2016b. I discuss the philosophy of “*Mìng xùn” and provide a philosophical translation of the text in Behr and Indraccolo, forthcoming.

141 “^Mìng xùn” 2/2-26.

142 Yì Zhōushū, 22. 
Questions aside what 'sī dé' means, ${ }^{143}$ "Mìng xùn” jiě brings up a point developed more fully later on in the two texts. At this juncture it seems misplaced. This is probably best explained as a transmission error in "Mìng xùn” jiě, a hypothesis stated previously by the Qíng scholar Táng Dàpéi 唐大培 (fl. 1836) in his study of the Yì Zhōushū. ${ }^{144}$

Other than this obvious break, the changes between the two texts are mostly minor. They largely fall into one of the categories described by Edward Shaughnessy in his study of the textual variants. Shaughnessy groups the differences between the two texts in five types, classed as follows: writing or copying errors; classifier variation; phonetic loans; variants caused by graphic similarity; the addition or deletion of words. He further includes one instance of a 'pseudovariant'. 145

Shaughnessy's study shows, to my mind, the instability of a fully stable text in writing-supported text performance. In a way “^Mìng xùn” thus compares to "Zīyī" of the Warring States. However, "Zīyī" is organised in a strict system of separate building blocks of which each is structured by a fixed template of Shì, Shū and ž phrases, connected by the text's authorial voice which links them together, thus serving as archive of cultural capital. Not so "Mìng xùn". It is an argument-based text in the traditions of Shu that develops a sophisticated dialectical philosophy of ruling. Rather than explaining its stability by reference to compact compositional features we must explain it otherwise: its prevalence rests in written composition.

“^Mìng xùn” is an extraordinary text. In its stability it is equally an exception to the rule as it is a case in point. It is an exception insofar as it contradicts the point of Shū as a genre that enables conceptual groupings to use steady components in an archaic speech register to produce an argument of new significance. It is a case in point, however, in that “^Mìng xùn” testifies to the literalisation of Shū where the primacy is shifted from modular clusters appropriated from the cultural capital of the wider meaning community of the Zhōu oecumene to increasingly stable texts. “^Mìng xùn” thus confirms the point of heightened forms of textualisation in stabilising manuscript cultures where Shū steadily become literature - or, as in “^Mìng xùn”, philosophy. It further shows that the models

143 The Qīng scholar Pān Zhèn 潘振 relates it to the gentleman scholar (Yì Zhōushū, 22). Shaughnessy 2016b: 133 renders it accordingly as ‘Overseer of Virtue'. I disagree with that choice because it introduces an unnecessary disbalance and weakens the argumentative pattern of the system as laid out in “^Mìng xùn”. I prefer reading it instead parallel to the next phrase as a V-O construction.

144 Táng Dàpéi, Yì Zhōushū fēn biān jùshì, 24. Quoted from Shaughnessy 2016b: 120.

145 Shaughnessy 2016b. 
discussed in this study are not mutually contradictory. We should not think of them as one scenario replacing the other in a linear progression. Different degrees of text stability and modular cultural appropriation can happily coexist.

\subsection{Conclusion}

While the literalisation of old cultural capital in the traditions of Shū clearly suited private text consumption, this was probably not their primary purpose. Rather, we should assume that despite their written primacy the texts composed at the time were still overwhelmingly produced for a form of delivery which had an oral aspect to it. This is discernable from physically visible features of the manuscripts-for instance perspective markers and other reading support-as well as the structural features of the texts, such as the dramatisation of the reported event through framing and other evocative elements. Written Shū therefore often require a certain 'public' as their audience, the meaning community of those days. But the groups for whom the texts were produced, and who repeatedly reproduced these texts for their ends, were of course not static. Naturally the texts changed too. This took different forms. Often it led to increased layers of complexity in these texts. Speech is reduced. Frames and other narrative features now pad the text to furnish it with quasi-historical elements that contextualise the account in a certain, if invented, setting. Even short texts increasingly produce an extended event that covers more expansive time periods in their narratives, not any longer just the primary event of the-predominantly royal-speeches. But the processes just described are dialectical. The thus produced, stand-alone, argument can become modular too and reoccur elsewhere in another context or narrative. In the long run the said processes led to the decrease of the oral dimension of some of these texts, increasing their narrative (or, as in “^Mìng xùn”, structural) appeal instead. This is certainly the case of text development in Shū traditions' longue durée, as seen from the imperial counterparts to their manuscript texts in the Shàngshū. A text such as "*Mìng xùn” in many ways foreshadows later developments. Still, despite this tendency toward an increased narrativisation and philosophication of written Shū, one point never fully ceased to play out: the purpose of Shū as a communal-political mythomoteur, ${ }^{146}$ in promoting the agendas of dynamic meaning communities and their invented traditions, as we shall see next.

146 A 'mythomoteur' is constitutive in giving a group, ethnic or otherwise, a sense of purpose, sociopolitically, socioreligiously, or dynastically. It was first used by Ramòn d'Abadal i de Vinyals 1958 and further developed by John Armstrong 1983 and Anthony D. Smith 1986. 